\title{
Gut Inflammation: Current Update on Pathophysiology, Molecular Mechanism and Pharmacological Treatment Modalities
}

\author{
Gyires K.*, Tóth V.E. and Zádori Z.S.
}

Department of Pharmacology and Pharmacotherapy, Faculty of Medicine, Semmelweis University, Nagyvárad tér 4., 1089 Budapest, Hungary

\begin{abstract}
Inflammatory bowel disease (IBD) is a chronic and relapsing inflammatory condition of the gastrointestinal tract. The two main forms of IBD are Crohn's disease and ulcerative colitis. According to the recent concept the disease is caused by a combination of factors, including genetics, immune dysregulation, barrier dysfunction and the change in microbial flora. Environmental factors, such as changes in diet, antibiotic use, smoking or improved domestic hygiene (e.g. eradication of intestinal helminths) probably contribute to the development and increased prevalence of IBD. Dysregulation of mucosal immunity in IBD causes an overproduction of inflammatory cytokines which resulted in uncontrolled intestinal inflammation. Based on extensive research over the last decade, besides the conventional therapy, there are several novel pathways and specific targets, on which focus new therapeutics. New therapeutics aim 1./ to correct genetic susceptibility by stimulating NOD2 expression, TLR3 signaling or inhibition of TLR4 pathway, 2./ to restore the immune dysregulation by inhibition of pro-inflammatory cytokines (TNF- $\alpha$, IL-6, IL-13, IL-17, IL-18, IL-21), Th1 polarisation (IL-2, IL-12, IL-23, IFN$\gamma$ ), T-cell activation, leukocyte adhesion, as well as by immunostimulation (GM-CSF, G-CSF) and anti-inflammatory cytokines (IL-10, IL-11, IFN- $\beta-1 \mathrm{a}), 3 . /$ to restore mucosal barrier function and stimulate mucosal healing by different growth factors, such as GH, EGF, KGF, TGF- $\beta$, VEGF, 4./ to restore the normal bacterial flora by antibiotics, probiotics. However, in spite of these numerous potential targets, the true value and clinical significance of most of the new biologics and molecules are not clear yet.
\end{abstract}

Keywords: Inflammatory bowel disease, colitis, microbiota, pattern recognition receptors, pro-inflammatory cytokines.

\section{INTRODUCTION}

Inflammatory bowel disease (IBD) is a chronic and relapsing inflammatory condition of the gastrointestinal (GI) tract. The two main forms of IBD are Crohn's disease (CD) and ulcerative colitis (UC), though other forms are also known, which are also classified as not typical IBD (e.g. collagenous colitis, lymphocytic colitis).

The cause of IBD is not exactly known. The recent consensus is that IBDs are initiated and perpetuated by an impaired immune response against the gut microbiota in genetically susceptible individuals $[1,2]$ and the disease is caused by a combination of factors, including genetics, immune dysregulation, barrier dysfunction, change in microbial flora and environmental influences (see reviews [3-7]).

Though UC and CD share some common clinical symptoms, the two diseases possess very distinct features. First of all, the location of the inflammation is different; $\mathrm{CD}$ can develop at any part of the intestine, though most of the cases are localized at the terminal ileum. In contrast, in UC the inflammatory process is restricted to the colon and the rectum. Moreover, the pathological changes in $\mathrm{CD}$ affect the whole bowel wall and manifested as transmural lesions, while in UC the inflammation is restricted to the mucosa (epithelial lining of the gut). Also differences in immunological response of intestinal mucosa have been described. CD is associated with the activation of types 1 and 17 T-helper (Th) cells in response to interleukin (IL)-12, IL-18, IL-23 and transforming growth factor $\beta$ (TGF- $\beta$ ), and activation of these cells results in increased secretion of the pro-inflammatory cytokines IL-2, IL-17, interferon (IFN)- $\gamma$ and TNF- $\alpha[8,9]$. In patients with UC the mucosal inflammation of the colon is mainly associated with a Th2 cell activation mediated by IL-4, IL- 5 and IL- 13 that results in an increased level of IL-13 [10, 11]. However, in both cases T-cells are also activated by direct contact with antigens [12].

*Address correspondence to this author at the Department of Pharmacology and Pharmacotherapy, Semmelweis University, Nagyvárad tér 4., 1089, Budapest, Hungary; Tel: 36-1-210-4416; Fax: 36-1-210-4412;

E-mail: gyirkla@net.sote.hu
As regards the clinical symptoms, body weight loss and fever are more common in $\mathrm{CD}$. Ulcerations, granulomas, and bowel fistulas are characteristic for $\mathrm{CD}$, in contrast, $\mathrm{UC}$ affects the mucosa in a continuous manner. Moreover, smoking was found to be protective against UC and might improve its course, but seems to increase the risk of developing $\mathrm{CD}$ and worsens its course [13].

On the other hand, extra-intestinal manifestations (liver problems, arthritis, skin manifestations and eye problems) can develop in both CD and UC. Some patients have an extra-intestinal manifestation as their first symptom of the disease, while they still have only mild gastrointestinal manifestation, or none at all. Anemia is the most prevalent extraintestinal complication of both IBDs [14, $15]$.

The chronic inflammation of the gut causes wide-ranging clinical symptoms in both forms, like nausea, diarrhea (which is often porridge-like in $\mathrm{CD}$, while mucus-like with blood in UC) or abdominal pain $[16,17]$.

$\mathrm{UC}$ or CD patients have increased risk for colorectal carcinoma (CRC). Patients with UC and Crohn's ileocolitis have an elevated risk of developing colon cancer, while patients with $\mathrm{CD}$ and enteritis have an elevated risk of developing small-bowel cancer $[18,19]$. The cumulative risk for developing colorectal cancer was $8 \%$ at 22 years from onset of symptoms for Crohn's colitis and $7 \%$ at 20 years from onset of symptoms for UC, as it accounts for one in six of all deaths in IBD patients [20].

The high incidence and prevalence of IBD (worldwide incidence of UC and CD varies between 0.5-24.5 and 0.1-16 individuals per 100.000 inhabitants, respectively) [21], and the costs of the long-term and only symptomatic treatment of the patients place a significant burden on the healthcare system: the expenses exceed 1.7 billion dollars per year in the United States [22], and are in similar range in European countries.

Although in the last decade our knowledge about the pathomechanism of IBDs greatly expanded (which is also clearly demonstrated by the continuously rising number of publications in this field), and several important milestones have been achieved, dis- 
tinction between causing events and secondary consequences is still challenging.

The aim of this review is to shortly summarize the current knowledge and newest findings in the pathomechanism of IBD as well as to overview some of the therapeutic targets and strategies (convential and novel ones) for the treatment of IBD.

\section{PATHOMECHANISM}

\subsection{Genetic Susceptibility}

The familial aggregation of IBD has already been observed several decades ago and studies conducted on twins also confirmed the importance of hereditary factors in the pathogenesis of IBD (especially for $\mathrm{CD}$ ), though they also highlighted the role of environmental trigger factors [23-27].

Genome wide association studies (GWASs) performed during recent years provided better insight into the genetic background of IBD. They revealed 163 genomic susceptibility loci associated with IBD so far, 110 with both disease phenotypes, and further 30 and 23 associated selectively either with CD or UC, respectively [28, 29]. The considerable overlap of susceptibility loci in CD and UC indicates that these two IBD phenotypes share several common factors in their pathogenesis.

Although the exact functional role of several IBD susceptibility genes still remains to be established, many of them are associated with host immune functions, including both innate and adaptive immunity.

The first susceptibility gene identified for CD was NOD2/ CARD15, which brought the role of innate immunity and pattern recognition receptors (PRRs) in the pathogenesis of IBD to the fore. As described in the next section, PRRs play an essential role in the host microbial interaction by sensing conserved microbial structures (pathogen-associated molecular patterns, PAMPs). Binding of PAMPs results in the activation of multiple signaling pathways including nuclear factor- $\kappa \mathrm{B}(\mathrm{NF}-\kappa \mathrm{B})$ and mitogen activated protein kinases (MAPKs), which in turn induce the production of inflammatory mediators and also initiate multiple cellular processes, including cell proliferation and differentiation [30-32]. NOD2, a member of the nucleotide-binding oligomerization domain (NOD)like receptor (NLR) family, recognizes muramyl dipeptide (MDP), a component of peptidoglycan (PGN) in nearly all bacteria [30]. The three most common NOD2 mutations, a frame-shift insertion mutation (3020insC) and two missense mutations (R702W and G908R) result in impaired recognition of MDP and in loss of NF$\kappa \mathrm{B}$ activation in response to lipopolysaccharide (LPS) and PGN [33-36]. Several groups confirmed the association of NOD2 with $\mathrm{CD}$, but interestingly, no such connection was found in Japanese individuals [37]. This is in line with other findings (see below) indicating that genetic determinants can differ significantly between populations.

In the last 2 decades several other PRR genes have been associated with IBD. A british group reported that a complex insertion/deletion polymorphism in NOD1/CARD4 (+32656) may contribute to the development of IBD and can result earlier onset and extra-intestinal manifestations [38], but other groups could not reproduce these findings in German [39], Scottish and Swedish patients [40].

Single nucleotide polymorphisms (SNPs) in Toll-like receptor (TLR) TLR1 and TLR2 genes (R80T and R753Q) were found to increase the risk of pancolitis in UC, but did not increase the susceptibility to disease development [41].

Several studies have been conducted to identify the role of the TLR4 gene in the pathogenesis of IBD, but similarly to NOD2, substantial heterogeneity was found between populations. The D299G SNP was associated with IBD in Belgian [42], German [43, 44], Greek [45] or Australian [46], but not in Southern Italian [47],
Hungarian [48] or New Zealand patients [49, 50]. Nevertheless, meta-analyses have provided evidences for an association between D299G and IBD [49, 50]. Similar discrepancies were observed with the T399I SNP, because significantly increased allele and carrier frequencies for this mutation were observed in patients with UC in a German cohort [44], while other groups could not demonstrate such association $[45,47,49,50]$.

The importance of PRR mutations in the development of IBD is further supported by the findings that a TLR9 polymorphism (1237T/C) was significantly higher in patients with CD [50], while polymorphism in the CARD9 gene (rs10870077), which encodes an adaptor molecule of PRR signaling, was associated with both CD and UC [51, 52].

Beside PRR genes GWASs have identified several other susceptibility genes, which has led to better understanding of the pathomechanism. The identification of IBD associated polymorphisms in autophagy-related 16-like 1 (ATG16L1) and immunity-related GTPase family M protein (IRGM) genes has revealed that impaired autophagy, and the consequent defects in innate immune responses to intracellular pathogens may be critical components of the chronic inflammation in IBD [53-56]. IBD associated alterations in X-boxbinding protein 1 (XBP1) and orosomucoid-like 3 (ORMDL3) genes imply that changes in the unfolded protein response (UPR) and the failure to manage endoplasmic reticulum stress may also contribute to the pathogenesis, for example due to increased apoptosis of Paneth cells $[57,58]$. Mutations in the mucin genes (e.g. MUC1, MUC19) or in the prostaglandin receptor EP4 gene (PTGER4) can lead to impaired mucosal barrier functions [51, 59], while genetic variations in the IL18RAP [52], IL23R [60, 61], STAT3 [62] or SMAD3 [51] genes highlight the importance of failures in the adaptive immune responses in IBD.

\subsection{Immune Dysregulation}

The intestinal mucosa is continuously exposed to a vast number of antigens (both dietary and microbial), which are recognized by the mucosal immune system. Under normal circumstances it distinguishes between beneficial and pathogenic microbes - it tolerates normal commensal bacteria, while eliminates invading pathogens. Today it is widely accepted that abnormal immune regulation is a key factor in the pathomechanism of IBD and alterations in both innate and adaptive immunity have been observed. This section shortly overviews the key players of the immune system and their contribution to IBD. For more comprehensive recent immunological reviews see e.g. [63-66].

The pattern recognition receptors (PPRs) play a key role in the bacteria-host interaction. These innate immune receptors are expressed by different cells of the intestinal mucosa (like dendritic cells (DCs), macrophages and intestinal epithelial cells (IECs)), and recognize conserved microbial structures (PAMPs). Probably the best-characterized family of PRRs are the Toll-like receptors (TLRs). This family comprises 13 members in mammals, ten in humans (TLR1-10) and 12 in mice (TLR1-9, TLR11-13) [67]. Most TLRs (TLR1, 2, 4, 5, 6 and 11) are localized on the cell surface, where they recognize mainly bacterial cell wall components (LPS of Gram negative bacteria by TLR4, lipoproteins from Grampositive bacteria by TLR1, 2 and 6 , flagellin by TLR5), while some members in this family are localized intracellularly in the endosomes (TLR3, 7, 8 and 9) and recognize viral or bacterial nucleic acids $[68,69]$.

The family of NOD-like receptors (NLRs) includes 23 members in humans and 34 in mice $[31,69]$. These cytoplasmic receptors contain a leucine-rich repeats (LRR) domain, which senses bacterial ligands, a central NOD domain (also called NATCH domain) required for activation and an $\mathrm{N}$-terminal effector domain that mediates interactions with other signaling proteins. Based on the effector domain five subfamilies can be distinguished, these are NLRA (also called CIITA, which contains an acidic domain), NLRB (or NAIP, 
which contains baculovirus inhibitor repeats (BIR)), NLRC (or NOD, which possesses a caspase recruitment domain (CARD)), NLRP (or NALP, contains a pyrin domain (PYD)) and NLRX (contains an unidentified domain) [30, 69, 70].

Further PRRs are the retinoic acid-inducible gene-I (RIG-I)-like receptors (RLRs), like RIG-I, MDA5 and LGP-2, which are also intracellularly localized and sense primarily viral RNAs [71], and the C-type lectin receptors (CLRs), including Dectin-1, Dectin-2, mannose receptor, C-type lectin receptor DC-SIGN and Mincle, which play an essential role in antifungal immunity [72, 73].

As mentioned above, PRRs are expressed by various cells in the intestinal mucosa and their activation modulates inflammatory processes at various levels. At first, they regulate the barrier function of the mucosa, which is the front line of defense against intestinal pathogens. The damage of IECs and their barrier function leads to an increased penetration of the microbes in the gut wall, which in turn activates immune cells and causes inflammation. Several studies demonstrate barrier disturbance in both animal colitis models and in patients with CD and UC [74-77]. In IBD IEC permeability increases both transcellularly (in which TNF- $\alpha$ has a major role) [78] and paracellularly via junctional complexes. For instance, an impaired tight junction sealing due to upregulation of claudin 2 and downregulation of claudin 5 , claudin 8 and occludin was reported in patients with active CD [79]. PRRs are involved in the modulation of epithelial integrity. Activation of TLR2 enhances the transepithelial resistance in vitro (through redistribution of the tight junction protein $\mathrm{ZO}-1$ ) and increases tight junction-associated IEC barrier integrity in vivo [80,81], and recent evidence suggest that NOD2 potentiates the TLR2-induced improvement of mucosal barrier [82]. Beside TLR2 also TLR9 has been shown to enhance transepithelial resistance [83], while the action of TLR4 is still not clear, since both improvement and disruption of the mucosal barrier have been described upon stimulation with LPS [82, 84].

PRRs are also able to enhance mucosal barrier functions via stimulating the secretion of antimicrobial peptides (AMPs), like cathelicidin and defensins. These peptides are secreted into the gut lumen by leukocytes and epithelial cells and regulate host microbial interaction and the composition of the commensal microbiota [74, 85]. The expression of $\alpha$-defensins by Paneth cells is associated with NOD2 signaling [86] and decreased $\alpha$-defensin production was observed in CD patients with NOD2 mutations $[87,88]$ although it has also been raised that reduced $\alpha$-defensin production is only the consequence, and not the cause of the inflammation [89]. Beside regulating the $\alpha$-defensin production, PRRs stimulate also the secretion of other AMPs. The activation of TLR4- and TLR2 increased $\beta$-defensin-2 expression by human IECs [90] and the expression of cathelicidin by mucosal macrophages was connected with TLR9 signaling in mice [91]. Taking the manifold effects of PRRs on AMP production into consideration, it is not unexpected that PRR signaling can also shape the structure of the gut microbial community. For example in TLR2 KO mice the proportion of Firmicutes and Proteobacteria was significantly higher and lower, respectively, in the gut microbiota [92], while NLRP6 deficiency was associated with increased representation of Prevotellaceae [93]. Hence, not only microbes can influence the host immune response via PRRs, but vice versa, PRRs can also influence the make up of the microbiota and control the load of commensal bacteria.

The healing of the intestinal mucosa in case of epithelial injury is essential to restore barrier functions. The controlled migration, proliferation and functional differentiation of IECs is regulated by various growth factors (including epithelial growth factor (EGF), TGF- $\alpha$, TGF- $\beta$ and fibroblast growth factor (FGF)), chemokines, regulatory cytokines (e.g. IL-6, IL-22) and trefoil peptides [94]. Several results suggest that epithelial restitution is influenced by PRRs. TLR2 induces gap junctional intercellular communication via connexin-43, and controls IEC restitution during acute and chronic inflammatory damage [95]. Similarly to TLR2, TLR4 is also likely to improve mucosal healing. Decreased epithelial proliferation was found in TLR4 deficient mice [96] and antibody directed against TLR4 impaired mucosal healing due to reduced expression of cyclooxygenase-2, prostaglandin E2 (PGE2) and amphiregulin [97]. Beside TLRs also NLRs are able to modulate the regeneration of the IECs. NLRP3 (also known as NALP3 or cryopyrin), which is one of the best-characterized NLRPs, recruits ASC (apoptosis-associated speck-like protein) and pro-caspase-1 into a large protein complex (inflammasome) to mediate the secretion of IL-1 $\beta$ and IL-18 [66]. Zaki et al. [98] demonstrated that NLRP3-, ASC- and caspase-1 KO mice are highly susceptible to dextran sulfate sodium (DSS) colitis, which is due to the decreased maturation and secretion of IL-18, and the consequent reduction of epithelial regeneration.

Beside regulating mucosal barrier functions, PRRs on DCs and macrophages are key factors in innate immunity.

DCs express a wide range of PRRs and interpret microbial patterns to direct other immune cells towards immunity or tolerance. They are able to sample luminal antigens directly by forming transepithelial dendrites [99]. Upon encounter with pathogens, DCs undergo rapid maturation characterized by upregulated expression of major histocompatibility complex (MHC) and co-stimulatory molecules (like CD80, CD86, CD40) and production of proinflammatory cytokines (IL-1, IL-6, IL-12, IL-23, TNF- $\alpha$ ). Then they migrate to the draining lymph nodes, where promote the proliferation and differentiation of naïve CD4 T-cells to Th1, Th2 or Th17 subsets. On the other hand, DCs are also important for the maintenance of homeostasis and tolerance against the commensal microbes via the production of anti-inflammatory cytokines such as IL-10 and TGF- $\beta$ and the production of tolerogenic regulatory $\mathrm{T}$ (Treg) cells [63, 100, 101].

Several studies demonstrate the active involvement of DC in the pathogenesis of IBD. The number of DCs expressing the maturation markers $\mathrm{CD} 80, \mathrm{CD} 83, \mathrm{CD} 86$ and $\mathrm{CD} 40$ is elevated in $\mathrm{CD}$ and UC [102-105]. DCs express also higher levels of TLR2 and TLR4 [102] and accordingly, show exaggerated response to LPS in IBD [106]. This may result in false recognition of commensal bacteria and induction of pro-inflammatory immune responses. Beside secreting higher amounts of pro-inflammatory cytokines, DCs are also less able to induce tolerogenic Foxp $3^{+}$Treg cells in CD [107].

The role of intestinal macrophages in IBD has also been intensively studied [63]. Similarly to DCs, macrophages also present antigens to T-cells and induce their differentiation to pro- or antiinflammatory subsets $[108,109]$. M1 macrophages produce proinflammatory cytokines TNF- $\alpha$, IL-12 and IL-23, and promote a polarized Th1 response, while M2 macrophages are characterized by production of IL-10 [109]. Thus, M2 macrophages may have important role in maintaining intestinal homeostasis and alterations in the levels of macrophages and their cytokines can contribute to the pathomechanism of colitis in animal models and in IBD. Accordingly, Smith et al. [110] found different cytokine profiles released by macrophages in healthy controls and CD patients after stimulation with heat-killed Escherichia coli or with the TLR2 ligand $\mathrm{Pam}_{3} \mathrm{CSK}_{4}$.

It is noteworthy, that Kamada et al. [111] observed the infiltration of unique CD14+ intestinal macrophages in the mucosa of CD patients at both inflamed and non-inflamed sites. These macrophages produced larger amounts of pro-inflammatory cytokines, such as IL-6, IL-23 and TNF- $\alpha$, than typical intestinal resident macrophages, and the authors raised the possibility that CD14+ macrophages may play a key role in the predominance of Th1 immune response found in CD [111].

The role of macrophage migration inhibitory factor (MIF), an other pro-inflammatory cytokine originating from both T-cells, innate immune cells and epithelial and endothelial cells in the pathomechanism of IBD is emerging $[112,113]$. MIF promotes the 
recognition of LPS and Gram-negative bacteria by upregulating the basal expression of TLR4 in the macrophages, thus serves as a key factor in the initiation of innate immune response [114]. The release of MIF stimulates the release of inflammatory cytokines, potentiates the recruitment of neutrophils to the inflammatory site and triggers metalloprotease (e.g. MMP-13) expression, leading to inflammation and tissue damage [112]. The expression of MIF was increased in DSS-induced colitis and administration of anti-MIF antibody significantly improved the DSS-induced symptoms [115]. Moreover, the levels of MIF in the sera of UC patients were significantly higher [116], which suggests that anti-MIF therapy may be a new therapeutic approach in IBD. Since increased MIF-expression is also associated with tumorigenesis [117], it is tempting to speculate that inhibition of MIF may also reduce the risk of colon cancer related to chronic inflammation.

As depicted above, the activation of PRRs expressed on innate immune cells and the consequent release of inflammatory cytokines results in different T-cell pattern. In CD mainly the Th1 cytokines (IL-12, TNF- $\alpha$, IFN- $\gamma$ ), while in UC predominantly Th2-associated cytokines (like IL-5 and IL-13) are dominating [118-120], and recognition of the importance of these cytokines led to the development of anti-cytokine biologic agents in the therapy of IBD. However, it has to be emphasized that the cytokine profile of these diseases is much more complex and even individual cytokines may possess diverse or opposing action in different clinical and immunological settings [64].

Furthermore, the recent discovery of the Th17 lineage has raised a new paradigm. Th17 cells differentiate from naïve CD4 Tcells, which process is induced and regulated by various cytokines, like IL-1 $\beta$, IL-6, IL-21, IL-23 and TGF- $\beta$ [121]. It has been revealed that Th17 cells, producing IL-17 and other pro-inflammatory cytokines play an essential role in the development of colitis in both mice and humans [122-124].

The activation of PRRs (both TLRs and NLRs) by the intestinal microbiota is essential for the development of Th17 cells, which is clearly demonstrated by the marked reduction of the Th17 cell number in germ-free mice $[125,126]$. Accordingly, stimulation of TLR5 on lamina propria DCs promoted the differentiation of Th17 cells [127], while TLR9-deficient mice had decreased number of lamina propria Th17 cells [128]. Moreover, the stimulation of DCs with MDP has been shown to enhance NOD2-mediated production of IL-1 $\beta$ and IL-23, which in turn promoted the IL-17 production by memory T-cells [129]. These results highlight the importance of PRRs also for adaptive immunity. In addition, although originally PRRs were thought to regulate innate immunity and only indirectly the adaptive responses, it turned out that also T- and B-cells express PRRs, and TLR or NLR agonists are able to directly influence their functions [32, 130, 131].

In summary, disruption of the mucosal barrier, increased and altered activation of DCs and macrophages, impaired balance between pro- and anti-inflammatory cytokines and polarisation of the adaptive immune response towards the effector T-cells all contribute to the pathomechanism of IBD, and PRRs are an important link between the participants of this complex system.

\subsection{The Microbiota}

The human gut is inhabited by $\sim 100$ trillion bacteria, which can consist of more than 1000 species overall and at least 160 species in each individual [132]. This indigenous bacterial community (the microbiota) is influenced by several factors (like diet, age or health status) and varies between individuals, although mainly only at the levels of strains and species, while most of the bacteria are members of the Bacteroidetes and Firmicutes phyla [133, 134]. The microbiota plays a fundamental role in energy metabolism and immunity, however, its role has also been implicated in several diseases, e.g. obesity, insulin resistance and IBDs (recently reviewed e.g. by [135-137]).
In the last decades considerable efforts have been made to identify a specific pathogen in IBD, and some bacteria (e.g. Mycobacterium avium spp. paratuberculosis or adherent-invasive Escherichia coli (AIEC)) have been proposed as causative agents, mainly in CD [138-140]. Moreover, various clinical studies were conducted to analyze the potential therapeutic effect of different antibacterial regimens (usually with the agents clarithromycin, metronidazole, ciprofloxacin or rifaximin) (see section 3.4.), but the results are conflicting [141, 142]. Now it is generally assumed, that instead of one (or few) distinct pathogen(s) an altered composition of gut flora, resulting in dysbiosis, and an overactive immune response may lead to chronic intestinal inflammation [143].

It is well established that the microbiota in IBD patients differs significantly from that of healthy people. One main difference is the decreased representation of the Firmicutes phylum. A reduction of the Clostridium leptum and coccoides groups (also known as Clostridium cluster IV and XIVa, respectively), and in particular the decreased amount of Faecalibacterium prausnitzii was observed by several groups [144-148]. Indigenous Clostridia may possess antiinflammatory properties by inducing IL-10 expressing Foxp $3^{+}$ $\mathrm{CD}^{+}$Treg cells in the colon [149]. Moreover, the loss of these bacteria may result in a decreased butyrate production, which is one of the most important bacterial products in the gut and exerts various anti-inflammatory effects via regulating the migration of neutrophils, inhibiting the production of pro-inflammatory cytokines and increasing the expression of tight junction proteins in colon epithelia $[136,150]$.

Another important genus in this phylum is the Lactobacillus, which contains several probiotic strains. Some of them (e.g. the Lactobacillus rhamnosus $G G$ strain) may possess beneficial effects in IBD [151] and recent evidences indicate that Lactobacillus salivarius Ls33 is able to inhibit experimentally induced colitis in a NOD2-dependent manner [152]. Furthermore, von Schillde et al. identified a Lactobacillus paracasei prtP-encoded protease named lactocepin, which degrades the pro-inflammatory chemokine IP-10 (interferon gamma-induced protein 10) and consequently alleviates colonic inflammation [153]. Thus, a reduced amount of Lactobacillus may contribute to the pathogenesis of IBD. Indeed, such alterations in the microbiota were observed by several authors [93, 145], though increased amounts [144] or no change of Lactobacillus levels [147] have also been reported.

Alterations in the Bacteroidetes phylum are also likely to contribute to the chronic inflammation. An increased representation of the Prevotellaceae has been documented in IBD patients [154, 155] and recently also in the intestines of mice with an impaired innate immunity [93]. It is assumed that these bacteria are colitogenic via producing sulfatases, that degrade mucus oligosaccharides and disrupt mucosal barrier function [156].

In contrast, Bacteroides fragilis is supposed to exert antiinflammatory effects. Its Polysaccharide A (PSA) component has been shown to inhibit Helicobacter hepaticus-induced experimental colitis in mice [157] and to directly induce the anti-inflammatory function of Foxp3 ${ }^{+}$Treg cells by acting on TLR2 [158]. Although early observations suggested a higher abundance of Bacteroides fragilis in IBD patients [159], recent studies found lower levels of this commensal [146, 147].

Similarly to Lactobacilli, Bifidobacteria from the Actinobacteria phylum also contain several probiotic strains and exert antiinflammatory effects. Bifidobacteria had beneficial effect in both animal models [160] and in patients with UC and CD [161-163], while lower count of Bifidobacteria was measured in IBD [147]. One potential protective mechanism is the activation of Tregs, as it has been observed in the case of Clostridia and B. fragilis (see above). The probiotic Bifidobacterium breve induced IL-10producing Treg type 1 cells by activating intestinal CD103+ dendritic cells via the TLR2/MyD88 pathway [164]. Another strain, 
Bifidobacterium lactis significantly decreased the colonic expression of various pro-inflammatory, dendritic and T-cell markers, like IL-6, TNF- $\alpha$, COX-2, CD40-L or IFN- $\gamma$ in mice [160].

In summary, there is growing evidence that an imbalance between colitogenic (e.g. AIEC) and tolerogenic bacteria (like Clostridia, Lactobacilli and Bifidobacteria) has a major role in the pathomechanism of IBD. Colitogenic bacteria can damage the epithelial barrier functions either directly or via producing toxins. For instance $A I E C$ strain LF82 disrupts the tight junction protein zonula occludens-1 [165] and through binding to the cell adhesion molecule CEACAM 6 can lead to abnormal expression of claudin 2 [166], while enteropathogenic Escherichia coli (EPEC) induces epithelial cell apoptosis by producing a bacterial toxin called cycle inhibiting factor [167]. Both results in an increased intestinal permeability, which permits the penetration of luminal antigens and microbes, that can stimulate pro-inflammatory responses.

However, the altered microbial flora can also induce inflammation indirectly, via reduced production of anti-inflammatory bacterial metabolites, like butyrate and other short-chain fatty acids (see above) [136] or via an altered metabolism of bile acids. Primary bile acids cholic acid and chenodeoxycholic acid are transformed by intestinal bacteria to their secondary forms, deoxycholic acid and lithocholic acid, which can disrupt intestinal barrier functions $[168,169]$. The recent results of Duboc et al. provide direct evidence of the connection between dysbiosis, bile acid dysmetabolism and chronic colonic inflammation [144]. They found a marked decrease in bacteria of the Firmicutes phylum and altered levels of secondary and conjugated bile acids in the faeces of patients with IBD.

\subsection{Environmental Factors}

Environmental factors may also play a role in the pathogenesis of IBD. As mentioned earlier, the composition of the microbiota is substantially influenced by diet and other life style factors [170, 171], and accordingly, dietary changes may contribute to the pathomechanism of IBD. Indeed, it was demonstrated that consumption of a diet high in saturated (milk derived)-fat promoted colitis in IL10 knock out mice [172]. The triggering factor was presumably the increased taurine-conjugation of bile acids, which increased the availability of organic sulfur and the amount of the sulfite-reducing microbe Bilophila wadsworthia, which in turn induced Th1 immune responses. Moreover, Kim et al. [173] reported that high fat diet altered the microbiota leading to an increased lumenal LPS content in the colon, which increased intestinal permeability and induced inflammation through a TLR4 signaling pathway.

In addition, vitamin D deficiency [174], as well as active and passive tobacco smoking [13, 175], air pollution [176] or improved domestic hygiene and sanitation [177] are additional factors that may modify the homeostasis of the intestinal mucosa. The observations, that IBD is common in Western countries, while uncommon in less developed areas, raised the intriguing hypothesis that improved hygiene and the consequent loss of routine exposure to parasitic worms (helminths) may play an important role in the pathomechanism of IBD [178].

Helminth infections may have several beneficial effects on the immune system (reviewed by $[179,180]$ ). They induce the formation of regulatory DCs, regulatory Treg cells and the production of anti-inflammatory cytokines (IL-10, TGF- $\beta$ ), while decreasing the formation of effector T-cells and pro-inflammatory cytokines (like IFN- $\gamma$, IL-17 or IL-12/23). Moreover, they seem to alter the composition of the microbiota and promote the growth of probiotic Lactobacillaceae [181].

\section{THERAPY}

The traditional therapeutic concept of CD is based on the socalled "step-up" approach: less toxic drugs (but often less effect- tive), are given in mild disease, whereas more effective (but potentially more toxic) agents are given in severe disease or in patients who are unresponsive to first-line therapy. Common conventional medications currently start with 5-aminosalicylic acid drugs, corticosteroids (prednisolone, methylprednisolone, budesonide) for $\mathrm{UC}$ as well as CD. Immunosuppressive agents such as azathioprine and 6-mercaptopurine were shown to be effective in both CD and UC, while methotrexate proved to be effective as a steroid-sparing agent in $\mathrm{CD}$. On the other hand, cyclosporine induced a pronounced therapeutic effect in severe, active UC [182, 183, 184].

A milestone in the therapy of $\mathrm{CD}$ was the introduction of infliximab, the first monoclonal antibody against TNF- $\alpha$, proved to be effective in induction of remission in $\mathrm{CD}$ patients who had been refractory to other therapeutic agents [185]. Later, it was demonstrated that both adalimumab, and certolizumab, monoclonal antibodies against TNF- $\alpha$, maintained the clinical remission [186, 187]. Surprisingly, etanercept (another anti-TNF- $\alpha$ agent, that fuses the TNF receptor to the constant end of the $\mathrm{IgG} 1$ antibody) failed to exert similar beneficial effect in CD [183, 188].

The more effective biological therapies are usually considered as a last option and only in case of refractory diseases, because they often cause severe adverse effects $[189,190]$. This strategy is recommended by current guidelines [191].

However, the natural course of the disease is not likely to be modified by conventional treatment [192]. Since anti-TNF- $\alpha$ therapy can induce and maintain clinical remission and mucosal healing, early administration of anti-TNF- $\alpha$ biological agents may prevent late complications [193]. Consequently, the question has been raised recently: whether to maintain or to reverse the traditional therapeutic pyramid [194]. On the other hand, it also has to be kept in mind that majority of CDs have benign course and immune modulators and biologics have severe adverse effects, that may result in increased risk of infections and malignant diseases (lymphoma) [195]. Consequently, treatment of the patients, who have a mild, benign course of the disease with highly potent biologics, such as TNF- $\alpha$ antagonists is not a good therapeutic choice, because of the risk of adverse effects.

Beside the side effects of anti-TNF- $\alpha$ agents, additional problems have been raised: among the primary responders only a third of patients will maintain remission after 1 year [196], and the therapy is often limited by a loss of efficacy. Therefore, finding novel targets and the development of novel therapeutic strategies became an urgent need.

The strategy to find new targets is based on the main pathological alterations that characterize IBD. Since the disease is caused by a combination of factors, including genetic susceptibility, immune dysregulation, barrier dysfunction, and the change in microbial flora, the new therapeutics aim to correct or restore 1./ the genetic alterations, 2./ the immune dysregulation, 3./ the barrier dysfunction and mucosal resistance $4 . /$ the altered composition of gut flora (Fig. 1).

\subsection{Correction of Genetic Alterations}

Under normal, healthy condition the intestinal mucus layer prevents exposure of IECs to luminal bacteria. Several mechanisms are involved in protection of intestinal epithelium against luminal microbiota, e.g. defensins (secreted by Paneth cells) and the production of immunoglobulin A (IgA). PRRs are involved in the production of cytokines necessary for the development of immunity and have crucial role in innate microbial sensing by IECs, DCs and macrophages [30]. Their activation initiates NF- $\mathrm{KB}$ and MAPK signaling pathways resulting in the production of pro-inflammatory cytokines and antimicrobial peptides [5, 197]. In addition, autophagy has a crucial role in the maintenance of intracellular homeostasis preventing abnormal accumulation of protein aggregates, intracellular components, such as organelles, apoptotic bodies, and 


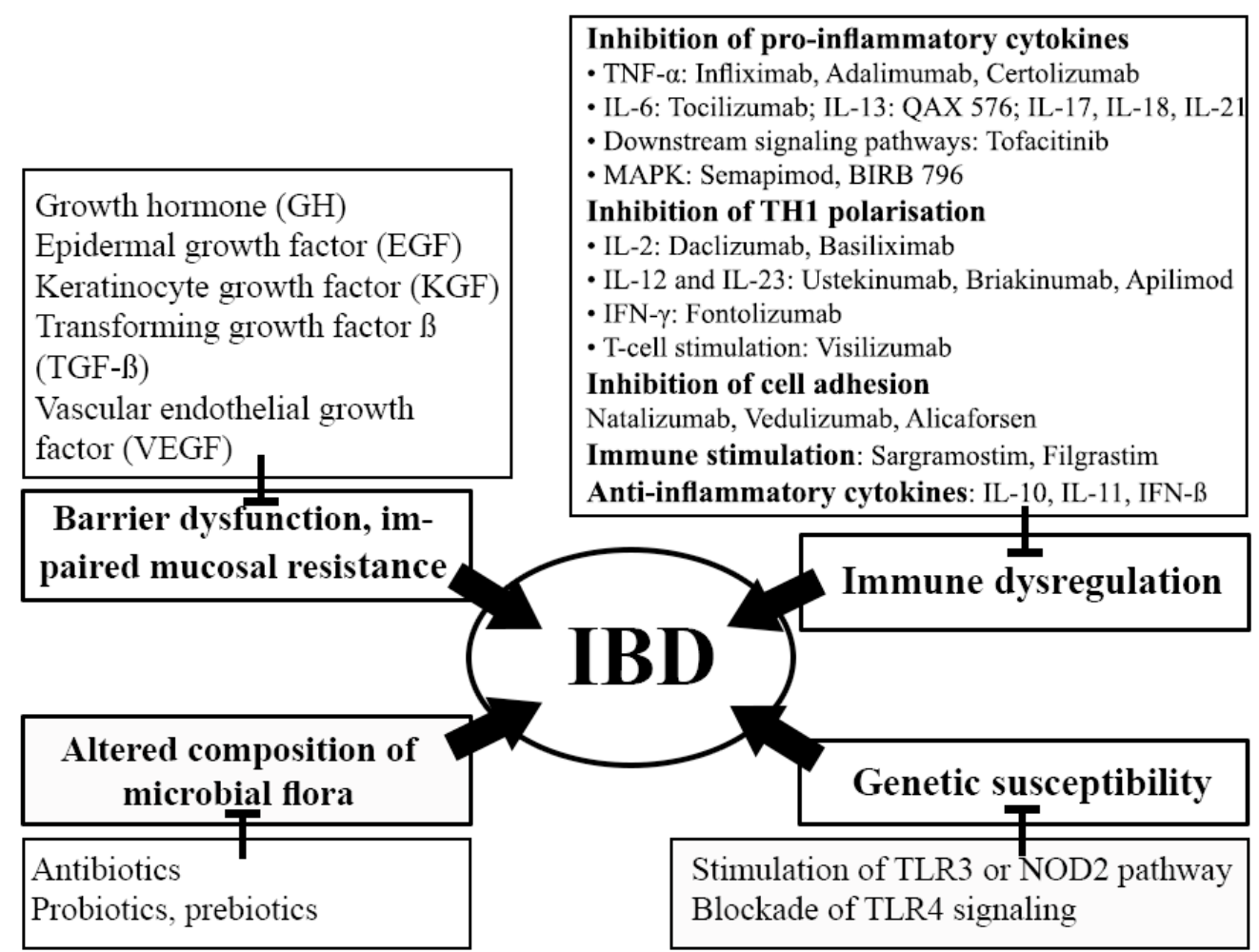

Fig. (1). Therapeutic approaches in IBD targeting different factors (genetic variations, immune dysregulation, barrier dysfunction and intestinal microbiota alterations), that are involved in the pathomechanism of IBD according to the recent consensus.

microbes [198]. One of the key proteins involved in the execution of the autophagic process is ATG16L1 [199].

Though a large number of genetic loci have been found to be associated with $\mathrm{CD}$, the polymorphism of two genes, NOD2/ CARD15 [200] and ATG16L1 seem to have particular importance in the development of the disease [201]. While in healthy subjects ATG16L1 encodes threonine at amino acid position 300 (ATG16L1*300T), ATG16L1 encoding alanine (ATG16L1*300A) instead of threonine at the same position increases the risk of the development of $\mathrm{CD}$, due to impairement in bacterial capture by autophagy [202].

Moreover, patients with $\mathrm{CD}$ showed decreased expression of mucosal TLR3 and increased expression of TLR4, which results in downstream release of inflammatory modulators, for example TNF$\alpha$ and IL-1 [203]. Consequently, stimulation of the TLR3 or NOD2 pathway may represent a new approach of the therapy of IBD. Experimental data suggest that activation of TLR3 (e.g. by synthetic viral RNA) or NOD2 were effective for prevention of DSS-induced acute colitis in the mouse [204-206], which implies that stimulation of TLR3 or NOD2 signaling may represent a new, successful therapeutic strategy for the treatment of $\mathrm{CD}$ in those patients who show reduced expression of TLR3 or carry NOD2 mutations [207]. On the other hand, blocking TLR signaling may represent another approach for IBD treatment, because TLR2 and TLR4 are upregulated in IBD [208]. Experimental data suggest that TLR4 blockade decreased inflammation in DSS-induced colitis in mice, but also interfered with colonic mucosal healing, since anti-TLR4 antibody treatment during recovery from DSS colitis resulted in defective mucosal healing (as described above) [209].

Attempts have been made to develop new TLR4 signaling inhibitors. Recently, arylidene malonate derivatives were found to suppress LPS-induced production of NF- $\kappa \mathrm{B}$, TNF- $\alpha$, IL- $1 \beta$ and nitric oxide [210], suggesting its potential therapeutic value for various inflammatory diseases. However, their real role in IBD remains to be clarified.

\subsection{Restoration of Immune Dysregulation}

Today it is widely accepted that abnormal immune regulation is a key factor in the pathomechanism of IBD and alterations in both innate and adaptive immunity have been observed. Dysregulation of mucosal immunity in IBD leads to an overproduction of inflammatory cytokines and trafficking of effector leukocytes into the intestinal mucosa, thus resulting in an uncontrolled intestinal inflammation. Under homeostatic condition there is a balance between regulatory (Treg) and effector T-cells (Th1, Th2 and Th17). Mucosal inflammation is induced either by an increase in the effector T-cell population and an increased production of pro-inflammatory cytokines (such as TNF- $\alpha$, IFN- $\gamma$, IL-1, IL-6, IL-12, IL-17, IL-23) or a reduced function of Treg cells and decreased level of antiinflammatory cytokines (e.g. TGF- $\beta$, IL-4, IL-10 or IL-11) produced by different immune cells located in the lamina propria of the intestinal mucosa. Cytokines may therefore be targets for IBD therapy [211]. Moreover, elimination of intestinal inflammation may be achieved either by reduction of effector T-cell populations or by increasing regulatory $\mathrm{T}$-cell activity $[5,212]$.

Several reviews have been published recently on the potential therapeutic agents in IBD that target the immune dysregulation [7, $12,188,190,211,213-218]$.

Restoration of the immune dysregulation may be achieved by several mechanisms, such as inhibition of 1./ pro-inflammatory cytokines, 2./ Th1 polarisation and proliferation, 3./ T-cell stimulation (anti-CD3 therapy), 4./ cell adhesion, as well as 5./ by immune stimulation (Granulocyte Macrophage Colony Stimulating Factor) /GM-CSF)/ and Granulocyte Colony Stimulating Factor /G-CSF/ and $6 . /$ by increase of anti-inflammatory cytokines. 


\subsubsection{Inhibition of Pro-inflammatory Cytokines 3.2.1.1. Inhibitors of $T N F-\alpha$}

TNF- $\alpha$ is a fundamental mediator of this abnormal immune response. TNF- $\alpha$ has two forms, a transmembrane and soluble form, and its action is mediated by 2 receptors, TNF-R1 (TNF receptor type 1, CD120a or p55/60) and TNF-R2 (TNF receptor type 2, CD120b or p75/80) [219] resulting in complex and differential actions. While the pro-inflammatory effects of TNF- $\alpha$ are mediated by TNF-R1, the immunoregulatory functions are independent from this receptor. Consequently, selective inhibitors of TNF-R1 that reduce the pro-inflammatory function of TNF- $\alpha$ without affecting its immunoregulatory effects, may represent a new therapeutic approach of IBD.

In the last 15 years, biological agents targeting TNF- $\alpha$ have significantly improved the therapy of IBD refractory to conventional drugs. The efficacy of this therapy alone reflects the pleiotropic effects of TNF- $\alpha$.

Infliximab, a monoclonal chimeric antibody, targeting human TNF- $\alpha$, became the first monoclonal antibody available for the treatment of CD and UC. The potency of this agent in moderate-tosevere $\mathrm{CD}$ and $\mathrm{UC}$ has been one of the most important advances in the treatment of IBD.

Infliximab also induces T-cell apoptosis, that contributes to its therapeutic effect [220]. Namely, in the gut, there is a tight control of activation and expansion of T-cells. T-cell expansion is limited by apoptosis, and T-cell resistance to apoptosis with consequent $\mathrm{T}$ cell expansion was observed in patients with IBD, which may contribute to the pathomechanism [221]. Hence, it may be raised that induction of apoptosis in T-cells and other effector cells may have therapeutic importance in the treatment of IBD and pro-apoptotic signaling might be a target for drug development [5].

It has been shown that some anti-TNF- $\alpha$ agents induce apoptosis in monocytes and lymphocytes both in vitro and in vivo [222, 223]. Consequently, apoptosis-induction seems to be an important part of the therapeutic action of TNF- $\alpha$ antagonists and differences in their apoptotic efficacy might contribute to the differences found in their clinical efficacy. In addition to infliximab, several other therapeutic agents that are effective in the treatment of IBD, including corticosteroids, sulfasalazine, azathioprine, 6-mercaptopurine and anti-IL-12 antibody, induce apoptosis of activated T-cells [222, 224-226].

Adalimumab, a fully human IgG1 monoclonal antibody to TNF$\alpha$, was found to be effective in patients with $\mathrm{CD}$ refractory to conventional therapy and in patients with an attenuated response to infliximab [211, 227, 228]. Recent study showed that adalimumab could induce and maintain clinical remission in patients with moderate-to-severe UC as well, who did not have a satisfactory response to steroids or immunosuppressive agents [229].

Certolizumab and certolizumab pegol (its PEGylated Fab' fragment with increased plasma half-life) are humanized TNF- $\alpha$ monoclonal antibodies. Majority of the human studies demonstrated their effectiveness in maintenance of response and remission in CD [230, 231]. However, Sandborn et al. failed to confirm the effectiveness of certoluzimab after 6 weeks treatment [232].

Etanercept is a genetically engineered fusion protein consisting of two recombinant human TNF p75 receptors linked to an Fc portion of human IgG1 fragment. It was found to be ineffective for the treatment of patients with moderate to severe CD in the same dose range that was effective in rheumatoid arthritis [233].

CDP571, an immunoglobulin G4 humanized monoclonal antiTNF- $\alpha$ antibody showed a slight and short lived reduction in clinical activity of UC [234]. It proved to be less effective than infliximab and further clinical development of CDP571 for the treatment of CD has been discontinued (see review [194]).
Novel TNF- $\alpha$ inhibitors have been developed, such as golimumab, dersalazine, HMPL-004 and ozoralizumab (ATN-103). These compounds are in various phases of the clinical trial process, and their real therapeutic values have to be determined [12]. In addition, recently a vaccine against TNF- $\alpha$ has been developed (TNF- $\alpha$ kinoid, Debio-01512), as a new mechanism for inhibition of TNF- $\alpha$ [196], and phase I/II clinical trials in patients with moderate to severe CD were found to be promising [235, 236].

\subsubsection{Inhibition of $I L-6$}

IL-6 has a fundamental role in immune regulation and inflammation. The IL-6 receptor (IL-6R) system has both a membranebound (IL-6R) and a soluble form (sIL-6R). Increased serum concentrations of IL- 6 and sIL-6R have been shown to correlate to clinical activity of $\mathrm{CD}$, and animal models have strongly suggested the therapeutic potential of anti-IL-6R monoclonal antibody. For example, anti-IL-6R monoclonal antibody reduced the symptoms of colitis in Th1 cell-mediated murine colitis model. Similarly, blockade of sIL-6R in vivo by a newly designed gp130-Fc fusion protein resulted in reduction of colitis activity and induction of apoptosis, indicating that sIL-6R suppresses mucosal T-cell apoptosis. Accordingly, it was shown recently that IL-6 induces the antiapoptotic genes BCL2 and BCL-XL [237]. These results suggest the therapeutic potential of anti-IL-6R monoclonal antibody in CD $[237,238]$.

Tocilizumab (also known as MRA) is a humanized IL-6 receptor antibody, recognizes both the membrane-bound and the soluble form of IL-6R and specifically blocks IL-6-induced actions [239]. Tocilizumab is expected to ameliorate the autoimmune inflammatory diseases characterized by IL- 6 overproduction and has been developed as a therapeutic agent for rheumatoid arthritis (see review [240]). Tocilizumab treatment of patients with active CD induced reduction of the disease activity index compared to the placebo group, however, remission of the disease was registered only at very low proportion of the patients [241]. The beneficial effect of tocilizumab was confirmed by Nishimoto [242].

\subsubsection{Inhibition of $I L-13$}

IL-13 has been shown to be pathogenic in IBD, particularly in UC. It impairs the function of the epithelial barrier and also causes apoptosis of epithelial cells [10, 11, 243, 244]. IL-13 overexpression in the inflamed mucosa is particularly characteristic for UC and IL-13 is considered as the major effector cytokine in UC [245].

The anti-IL-13 antibody anrukinzumab (IMA-638) as well as tralokinumab (CAT-354), a fully human anti-IL-13 antibody are under clinical studies (phase IIa) in patients with mild to moderate UC. $Q A X 576$, another fully human antibody against IL-13, is in phase I/II trials in patients with $\mathrm{CD}$, the final results are pending [246, 247].

\subsubsection{Inhibition of Mitogen Activated Protein Kinases (MAPKs)}

Expression of pro-inflammatory cytokines, which are critical in the pathogenesis of IBD, is regulated by one or more MAPK pathways. Accordingly, activation of several MAPK members was found in biopsies from the inflamed mucosa of CD patients [248].

CNI-1493 (semapimod), inhibitor of JNK/p38MAP kinases, showed significant clinical improvement of severe $\mathrm{CD}$, confirming the potential role of inflammatory MAPKs in the pathogenesis of CD [249]. In contrast, a highly potent inhibitor of p38 MAPK, BIRB 796 (doramapimod) was studied in chronic active CD in a multicenter, multinational trial with placebo control, and the results failed to show evidence for clinical efficacy [250].

Concerns with the use of MAPK inhibitors have been raised, for example inhibition of p38 and 42/44 MAPK reduces normal bactericidal activity of neutrophils [251]. Moreover, ubiquitous presence of the MAPK pathways and their involvement in several processes suggests that MAPK inhibition should be selective for an isoform, rather than general. 


\subsubsection{New Avenues Against Pro-inflammatory Cytokines or Downstream Signaling Pathways}

Currently, several novel agents have been developed to target either pro-inflammatory cytokines or downstream signaling pathways. Pro-inflammatory cytokines IL-17, IL-18 and IL-21 were found to be elevated in the inflamed intestinal mucosa of patients with IBD [252-254]. Monoclonal antibodies developed against these cytokines are currently in phase I/II clinical trials in patients with CD. Unexpectedly, secukinumab (AIN 457) targeting IL-17 in double-blind, placebo controlled study in patients with CD worsened the disease compared with placebo [255]. In contrast, inhibitor of the release of IL-17, vidofludimus (4SC-101/SC12267) showed beneficial effect in a single-arm, open-label study, indicating that it may be useful in maintaining clinical remission both in patients with CD and UC [256]. Further investigation is needed to clarify the modulatory role of IL-17 in IBD.

On the other hand, gut inflammation can also be restricted by blocking the downstream signaling pathways mediated by cytokines. Signaling molecules that interact with cytokine receptors are the Janus kinases (JAK), JAK1, JAK2 and JAK3, which play a fundamental role in the development and differentiation of immune cells.

Tofacitinib, inhibitor of JAK3 was developed recently [257], but various clinical efficacies have been experienced. A multicentre, double-blind, placebo controlled study with tofacitinib in patients with moderate to severe active CD showed no clinically significant response following 4 weeks of treatment compared with placebo, but in patients with moderate to severe UC it showed improvement in both clinical response and remission rates [258, 259].

\subsubsection{Inhibition of TH1 Polarisation and Proliferation}

\subsubsection{Inhibition of $I L-2$}

Inhibition of the binding of IL-2 to the IL-2 receptor results in inhibition of the growth, proliferation and differentiation of T-cells to 'effector' T-cells.

Basiliximab (chimeric monoclonal antibody) and daclizumab (humanized monoclonal antibody) are targeted against the $\alpha$-chain of the IL-2 receptor (CD25), and inhibit the binding of IL-2 to the IL-2 receptor. However, daclizumab failed to induce a significant action in UC [260]. Neither basiliximab increased the effect of corticosteroids in the induction of remission in patients with corticosteroid-resistant moderate to severe UC [261].

\subsubsection{Inhibition of $I L-12$ and $I L-23$}

CD is associated with an enhanced Th1 cytokine response, which results in increased production of IL-12, a pro-inflammatory cytokine, that stimulates the production of IFN- $\gamma$ and TNF- $\alpha$. IL-12 is also involved in the differentiation of naïve T-cells into Th1 cells. It is a heterodimeric protein with 2 subunits: the p35 and p40. The structurally similar cytokine IL-23 (its p40 subunit is identical to IL-12p40, and its p19 subunit shows certain similarities to IL-12 p35) has also an important role in intestinal inflammation, in conjunction with IL-6 and TGF- $\beta 1$. IL-23 stimulates naïve CD4+ T cells to differentiate to Th17 cells. The highly aggressive immune response together with IL-12/IL-23 could have a determining role in initiation and perpetuation of chronic intestinal inflammation in CD [262, 263].

Recently p40 peptide-based vaccines have been developed. Pretreatment of rats with the vaccines induced specific antibodies to IL-12 and IL-23, which was associated with improvement of intestinal inflammation and fibrosis, indicating that the vaccine may provide a potential approach for the long-term treatment of $\mathrm{CD}$ [264].

A human study showed that treatment with a human monoclonal antibody against IL-12 may induce clinical responses and remissions in patients with active $\mathrm{CD}$. This treatment is associated with decreased Th1-mediated inflammatory cytokines at the site of disease [265]

Ustekinumab, and briakinumab are human monoclonal antibodies against IL-12 and IL-23, both targeting the p40 subunit. Ustekinumab significantly increased the rates of response and remission as maintenance therapy, and it may be particularly useful in patients who previously did not respond to anti-TNF therapy [266]. Briakinumab, however, in patients with moderate to severe CD was not effective for the induction or maintenance of remission ([267].

Apilimod is an inhibitor of the transcription of IL-12 and IL-23. In a randomised controlled trial apilimod failed to induce significantly greater effect than placebo treatment [268].

\subsubsection{Interferon- $\gamma$}

IFN- $\gamma$ was found to be elevated in all genetic animal models of IBD and seems to have determining role in the development of Th1 responses. If the target of IBD therapy is to reduce Th1 responses, then inhibition of IFN- $\gamma$ represents one potential therapeutic approach.

Fontolizumab, a humanized monoclonal antibody to IFN- $\gamma$ was shown to have a beneficial effect on disease activity [12, 211, 269]. An other study suggested that though a strong clinical response was not induced by fontolizumab, a significant decrease in C-reactive protein levels was observed. Further studies are necessary to determine its efficacy [270].

\subsubsection{Inhibition of T-cell Stimulation}

Since intestinal inflammation may be resulted by an increased activity of the effector T-cell population with excessive inflammatory responses and $\mathrm{CD} 3$ is required for $\mathrm{T}$-cell activation, drugs that target T-cell activation may exert therapeutic effect in IBD.

Visilizumab, a humanized anti-CD3 monoclonal antibody was demonstrated to induce apoptosis in activated T-cells selectively, and enhance the production of IL-10, a potent anti-inflammatory cytokine [271]. It proved to be effective against T-cell transfer colitis [272]. The results of an open-label phase I human study with visilizumab in patients with severe corticosteroid-refractory UC suggested that it may be clinically beneficial [273].

Another study confirmed this beneficial effect of visilizumab in a pilot randomized phase I/II study. Visilizumab improved both symptomatic and clinical responses in severe, steroid-refractory UC, though, all patients experienced adverse reactions [274]. However, in a randomised, double-blind, placebo-controlled study visilizumab was not effective for severe, corticosteroid-refractory UC [275]. The same conclusion was drawn by Wood [276].

CD40 is also involved in T-cell activation. Humanized monoclonal antibody against CD40L has been developed, however in a phase II trial for CD due to side effect (thromboembolism) the trial was halted [277].

\subsubsection{Inhibition of Cell Adhesion}

Lymphocyte trafficking to the gut is a basically important step in the initiation and maintenance of intestinal inflammation in patients with IBD. Alpha 4 integrin, a cell-surface glycoprotein involved in the adhesion, migration and activation of immune cells, is expressed on most of the lymphocytes, and combined with either a $\beta 1$ subunit (that interacts predominantly with the endothelial ligands, vascular cellular adhesion molecule 1 /VCAM-1/) or a $\beta 7$ subunit (that interacts predominantly with the mucosal addressin cellular adhesion molecule 1 (Mad-CAM-1)) [278]. The interaction between $\alpha 4 \beta 7$ integrin and Mad-CAM-1 is important in mediating leukocyte homing to gut mucosa [279]. Several therapeutic agents have been developed that specifically target the $\alpha 4 \beta 7$ subunit of integrin.

Natalizumab, a humanized monoclonal antibody against the cell adhesion molecule $\alpha 4$-integrin subunit, was proved to be effective in experimental colitis both in the mouse and the rat $[280,281]$. 
Moreover, the effect of natalizumab has been studied also in humans, and it was shown to block the adhesion and migration of white blood cells into the gut and to reduce chronic inflammation associated with CD [282]. Reviews based on relevant literature and meta-analysis of the controlled trials of natalizumab suggested that the therapy was superior to placebo in inducing remission of $\mathrm{CD}$ [283, 284]. However, natalizumab therapy is associated with an increased risk of reactivation of latent John Cunningham (JC) virus, which causes the potentially fatal progressive multifocal leukoencephalopathy (PML). The risk to develop PML is increased by the presence of anti-JC virus antibodies, and previous or concomitant treatment with immunosuppressive (IF- $\beta 1$ or azathioprine) agents [285].

Vedolizumab (MNL-0002) is gut-specific, $\alpha 4 \beta 7$-integrinneutralizing monoclonal antibody, that appears to lack systemic effects. It was particularly effective in UC and also in CD, indicating that vedolizumab might be therapeutic option for the treatment of therapy-refractory patients [286]. A recent review evaluated the safety and efficacy of vedolizumab for the treatment of CD, and it was concluded that vedolizumab is an effective and well-tolerated drug [287]. Though it does not increase the risk of infection, it was demonstrated that vedolizumab may reduce the number of Treg cells and consequently their suppressive effect on colonic inflammation (see review [288]).

Alicaforsen (ISIS 2302) is an antisense oligodeoxynucleotide to ICAM-1 [289]. Experimentally, it inhibited the DSS-induced colitis both in mice and rats $[289,290]$, but in human studies both improvement of clinical symptoms and lack of effect have been shown in CD (see reviews $[12,211,291,292])$. In patients with active UC alicaforsen enemas induced a beneficial effect, and the drug was well tolerated [291].

\subsubsection{Immune Stimulation}

Though granulocyte macrophage colony stimulating factor (GM-CSF) and granulocyte colony stimulating factor (G-CSF) are hematopoietic growth factors, they stimulate cells of the innate immune system (neutrophils, macrophages and DCs). They have also been shown to be produced within Paneth cells of intestinal mucosa, and their receptors are expressed within IECs [293]. Moreover, GM-CSF has been demonstrated to promote proliferation within these cells [294].

GM-CSF has been shown to reduce DSS-induced colitis and decrease the levels of pro-inflammatory cytokines (TNF- $\alpha$ and IL$1 \beta$ ) in colonic tissue samples [295, 296]. These results were confirmed recently; GM-CSF decreased the DSS-induced colitis and the expression of pro-inflammatory cytokines. In addition, the duration of ulcer healing was shorter and epithelial regeneration was facilitated in GM-CSF-treated mice [295]. Based on these preclinical results, a potential role for GM-CSF in the therapy of patients with IBD has been raised.

Sargramostim (recombinant human GM-CSF) and filgrastim (recombinant human G- CSF) have been examined in several human studies and majority of them suggested a significant improvement and remission of CD ([297] and reviews [12, 298]). However, sargramostim in a phase III multicentre double-blind, placebo controlled study in patients with active $\mathrm{CD}$ failed to induce a significant difference in clinical efficacy compared to placebo. Further human studies are necessary to reveal their role in the treatment of IBD [211].

\subsubsection{Anti-inflammatory Cytokines}

\subsubsection{IL-10}

IL-10 reduces the production of pro-inflammatory cytokines IL$1 \alpha$, IL- 6 and TNF- $\alpha$, downregulates and controls the acute inflammation and thereby may improve the course of IBD. IL-10 polymorphisms have been shown to be associated with IBD and muta- tions in IL-10 and IL-10 receptor (IL-10R) in patients with very early onset IBD was observed [299].

However, Buruiana et al. [300] on the basis of a systematic review of the literature concluded that IL-10 does not appear to provide any benefit for the treatment of active $C D$.

\subsubsection{IL-11}

IL-11 besides its thrombocytopoietic properties improves the mucosal barrier function and inhibits the inflammatory reaction by reducing expression of NF- $\kappa \mathrm{B}$ and in turn IL-1, TNF- $\alpha$ and other proinflammatory peptides [301]. Therefore IL-11 was examined on experimental colitis in the rat induced by trinitrobenzene sulfonic acid (TNBS), where IL-11 exerted protective effect [302]. Recent findings confirmed the beneficial action of IL-11: administration of exogenous IL-11 was found to be protective against lethal colitis in TLR2-deficient mice (TLR2 is involved in maintaining epithelial barrier function) [303]. However, in a human study recombinant human IL-11 was less effective than prednisolone in the treatment of CD [304]

\subsubsection{Interferon- $\beta-1 a(I F N-\beta-1 a)$}

Data of the literature reflect conflicting results on the effect of IFN- $\beta-1 \mathrm{a}$ in IBD. Some studies indicate that IFN- $\beta-1 \mathrm{a}$ exerts a therapeutic effect, while others found that IFN- $\beta-1$ a did not produce a significant therapeutic action compared with placebo. Recent clinical trial in patients with $\mathrm{CD}$ came to the conclusion that there was no difference between the effects of the administration of IFN$\beta-1 \mathrm{a}$ and placebo $[305,306]$.

\subsection{Restoration of Barrier Dysfunction and Stimulation of Mu- cosal Healing and Resistance}

Repeated intestinal epithelial damage and the consequent disruption of the intestinal barrier function is a key mechanism of IBD $[3,6]$. Namely, the alteration of intestinal barrier function may result in translocation of commensal bacteria into the intestinal wall, leading to uncontrolled T-cell activation and inflammation. Damage of barrier integrity, with increased antigen and bacterial uptake is believed to be important in the pathophysiology of CD [4].

An intact barrier function of the intestinal epithelium prevents translocation of commensal bacteria into the mucosa. Consequently, though mucosal healing has been considered as a sign of complete healing of gut inflammation, it should be emphasized that mucosal healing can be considered as an initial step in suppression of inflammation [307]. In a systematic review Neurath and Travis [307] analyzed the influence of conventional therapeutic agents as well as the biologics on the healing of intestinal mucosal injury in IBD, and they concluded that while corticosteroids have little or no positive effects on induction/maintenance of mucosal healing in CD (but induced healing in patients with UC), azathioprine, in a lesser extent methotrexate, as well as natalizumab, infliximab, adalimumab and certolizumab pegol could induce mucosal healing [307].

Following injury of intestinal mucosa, IECs migrate into the damaged area to restore barrier integrity [298, 308], followed by proliferation of IECs to correct the epithelial defect. Finally, differentiation of IECs is necessary to restore mucosal barrier and epithelial function. These consecutive events (restitution, proliferation and differentiation) are mediated by regulatory proteins (such as chemokines), defensins, as well as by growth factors [298]. Growth factors have crucial role in cell restitution/proliferation/ differentiation, and in angiogenesis. Moreover, TGF- $\beta$ inhibits the differentiation of naïve T-cells to Th1/Th2 subtypes.

\subsubsection{Growth Hormone (GH)}

$\mathrm{GH}$, a regulatory peptide that stimulates aminoacid and electrolyte uptake by the intestine, decreases intestinal permeability and stimulates collagen synthesis by induction of the expression of insulin-like growth factor (IGF). IGF was shown to promote epithelial repair in intestinal inflammation in preclinical animal models. For 
example, recombinant human growth hormone induced protective effects in TNBS-induced colitis [309]. A preliminary study showed that human growth factor was effective in $\mathrm{CD}$, it improved the clinical symptoms (the number of liquid/soft stools, severity of abdominal pain and overall well being) and a statistically significant increase in circulating levels of IGF-1 was observed [310]. Further, placebo controlled human studies should be performed to determine the real place of growth factor in the therapy of IBD.

\subsubsection{Epidermal Growth Factor (EGF)}

Human recombinant EGF was shown to be effective in experimental colitis induced by TNBS given prophylactically, before the induction of colitis [311]. In UC patients EGF enemas administered parallel with mesalamine resulted in a significant improvement of symptoms [312], however, the effect of EGF enema alone (with placebo) has not been studied.

\subsubsection{Keratinocyte Growth Factor (KGF)}

KGF-1 and -2 are ligands of the fibroblast growth factor (FGF) family. KGFs may have role in wound healing and maintaining epithelial homeostasis. Expression of KGF-1 was found to be upregulated in patients with active $\mathrm{CD}$ and $\mathrm{UC}$, indicating that $\mathrm{KGF}$ may have role in the pathomechanism of IBD [313].

In animal models, KGF-2 proved to be protective against DSSinduced colitis given both prophylactically and therapeutically, both the clinical as well as the histological symptoms were improved significantly [314, 315]. However, human recombinant KGF-2 failed to improve symptoms in patients with moderate to severe colitis, when compared with placebo. The contradictory results gained from animal experiments and human studies were explained by miscalculation in estimating the target dosage in humans [316]. However, a recent study confirmed the previous finding; KGF-2 (and EGF) did not show efficacy in phase II trials concerning patients with either CD or UC (see review [298]).

\subsubsection{Transforming Growth Factor $\beta(T G F-\beta)$}

The TGF- $\beta$ superfamily in the intestinal epithelium controls cell proliferation, differentiation, apoptosis, as well as the activation state of differentiated cell types. The TGF- $\beta$ superfamily can further be divided into subfamilies and within the gut these include the TGF- $\beta$ and bone morphogenetic protein (BMP) subfamilies. TGF- $\beta$ superfamily ligands appear to facilitate the maintenance of normal epithelial homeostasis. Dysfunction of TGF- $\beta$ /BMP signaling within the intestinal epithelium has been raised to be involved in the pathogenesis of human colitis [317].

Recent preclinical studies demonstrated the role of BMP-7 both as a prophylactic and a therapeutic agent in experimental colitis induced by TNBS in the rat. Cytokine analysis of treated rats showed a reduced mRNA expression of pro-inflammatory cytokines, like IL- 6 , TNF- $\alpha$, and ICAM- 1 and decreased expression of pro-fibrogenic cytokines (TGF- $\beta 1$ ) [318].

\subsubsection{Vascular Endothelial Growth Factor (VEGF)}

VEGF has basic role in the regulation of angiogenic processes during both development and in pathologic conditions (inflammation or tumorgenesis). Six mammalian VEGF family ligands (VEGF-A - VEGA-F) and 3 distinct receptors (VEGFR-1, VEGFR2 and VEGFR-3) have been described. In rats, anti-VEGF antibody was investigated in colitis induced by iodoacetamide given intracolonically, and the results showed markedly less severe colitis as well as significant reductions in pro-inflammatory cytokines compared with controls. The beneficial effect of anti-VEGF antibody on colitis may be due to its moderating effects on vascular permeability and inflammatory cell recruitment [319]. Further studies showed that the levels of VEGF-A and VEGFR-2 were increased in patients with IBD as well as in DSS-treated mice. Furthermore, overexpression of VEGF-A in mice worsened DSS-induced colitis, whereas administration of a soluble VEGF receptor led to decreased colonic inflammation [320]. Another angiogenic factor, placental growth factor (PIGF), has also been suggested to be a marker of pathologic angiogenesis and may play a critical role in pathogenesis of UC. Accordingly, inhibition of pathologic angiogenesis by either antiVEGF or anti-PIGF, was demonstrated to be a new approach to attenuate UC [321, 322].

The role of additional growth factors, such as glucagon-like peptide or trefoil factors have been raised to be involved in healing and restoration of mucosal integrity in IBD [298, 323]. Some of them have been studied in clinical trials or experimental colitis models and their potential role in the treatment of IBD remains to be further analyzed.

However, it should keep in mind that both UC and CD are associated with dysplastic lesions and with increased risk of the development of colorectal cancer [324]. Since growth factors may induce stimulation of dysplastic tissues, growth factor therapy represents a potential risk for induction of malignant alterations in these patients [325].

In contrast, the recent results of Dube et al. [326] suggested that EGF receptors by modulating epithelial regeneration and reducing inflammation might limit the subsequent tumorgenesis. Namely, since chronic inflammation increases the risk of the development of cancer in IBD patients, disrupting the cycle of inflammation and epithelial injury may result in reduction of cancer risk. The authors showed that inactivation of the EGF-receptors accelerated the progression of colorectal tumors in mouse models of colitis, which suggests that therapy with EGF may reduce long-term cancer risk.

\subsection{Normalization of the Altered Composition of Microbial Flora}

Convincing evidence from both animal models and clinical observations indicate that the microbiota is the most probable factor that initiates chronic inflammation in CD. In accordance with this concept, antibiotics are one potential therapy in the treatment of active CD and UC. Moreover, it was shown that intestinal bacteria are necessary for the development of experimental colitis in the mouse [225, 327].

Bacterial adhesion and invasion into the intestinal mucosa may be particularly important in the development of intestinal mucosal inflammation, e.g., as in the case of Escherichia coli [328]. Though several pathogens have been supposed to be involved in the development of IBD (see section 2.3.), none of them have been proven to have a causal role, rather, microbial antigens that are present in the intestinal lumen under normal conditions seem to drive intestinal inflammation [213].

The microbiota is involved in both beneficial and deleterious processes in the intestinal tract. Epithelial cells may act as a mucosal protective and antimicrobial defensive system. Antimicrobial peptides, such as defensins, released by IECs and Paneth cells, play an essential role in host defense. Clinical studies showed reduced expression of both $\alpha$ - and $\beta$-defensins and the consequent reduced killing of certain microorganisms by the intestinal mucosa of patients with CD [329]. These findings indicate that defensin deficiency should be corrected in patients with $\mathrm{CD}$. The nuclear receptor peroxisome proliferator-activated receptor gamma (PPAR- $\gamma$ ) plays an essential role in intestinal homeostasis. PPAR- $\gamma$ was shown to function as an antimicrobial factor by maintaining constitutive epithelial expression of a subset of $\beta$-defensin in the colon. Defective killing of several intestinal microbiota in colonic mucosa of PPAR- $\gamma$ mutant animals, for example Candida albicans, Bacteroides fragilis, Enterococcus faecalis and Escherichia coli was demonstrated recently [330]. Furthermore, the PPAR- $\gamma$ agonist rosiglitazone is a potent inducer of a subset of $\beta$-defensin in mouse colon. Accordingly, rosiglitazone was shown to be efficacious in mild-tomoderate UC [331]. This finding raises a new potential mechanism for the improvement of gut barrier function in CD. 
Enteric flora is altered in IBD patients. As intestinal bacteria are supposed to be involved in the pathogenesis of the disease, the therapeutic value of antibiotics in the treatment of IBD have been studied. Metronidazol, ciprofloxacin, rifamixin failed to induce a significant effect in UC, and also the results of clinical studies with metronidazole, ornidazole, ciprofloxacin, tobramycin, clarithromycin, co-trimoxazole and anti-mycobacterial agents in CD are conflicting and not convincing [7, 141, 142].

Since gastrointestinal microbiota has prominent role in driving inflammation in IBD, treatments that modulate the intestinal microbiota have been intensively analyzed. To counterbalance harmful bacteria, manipulation of the bacterial flora with probiotics (nonpathogenic, beneficial bacteria) and prebiotics (dietary components that stimulate the growth of beneficial bacteria) is a potential alternative. Several mechanisms have been raised to be responsible for the potential beneficial effects of probiotics, such as production of bactericidal substances, competition with pathogens and toxins for adherence to the intestinal epithelium, enhancement of the innate immunity, modulation of pathogen-induced inflammation via TLRregulated signaling pathways and stimulation of intestinal epithelial cell survival and barrier functions (see review [332]). Results from experimental models of colitis suggest that TLR2, TLR4 and TLR9 are necessary for some probiotics to exert their anti-inflammatory effects in vivo [333]. However, in the light of literature probiotics show variable evidence for their efficacy [334, 335]. E.g. probiotics (Lactobacillus $G G$ ) were found to be ineffective in preventing recurrence after curative resection for CD [336]. Similarly, Mack [337] concluded in his review that there is little evidence and not enough convincing proof from trials for the effectiveness of probiotic in CD as well as in UC, though, clinical practice guidelines suggests their potential benefit in selected patients.

Anderson et al. [338] recently published a review focusing on the efficacy of fecal microbiota transplantation (FMT). FMT was administered via colonoscopy/enema or via enteral tube. In patients treated for their IBD, the majority experienced a reduction of symptoms and disease remission. It was concluded, that though faecal microbiota transplantation may be an effective treatment of IBD, the evidence for the therapeutic effectiveness is limited and weak. Further randomized, controlled clinical studies are required to clarify the potential therapeutic value of FMT.

As mentioned above, IBD is common in Western countries, where helminths are rare, and uncommon in less developed areas, which may be associated with poor sanitation and the concomitant helminth infections. Experimental data are in agreement with this assumption: it was shown that mice colonized with helminths are protected from the development of experimental colitis in various animal models (TNBS, DSS, IL-10 KO, T-cell transfer colitis) due to the activation of Treg cells and inhibition of effector T-cells [180]. Efficacy of helminths in CD and UC has been studied and the results suggest that Trichuris suis ova treatment was safe, and efficacious and may offer alternative therapeutic possibility for CD. Similar beneficial effect was observed in patients with UC (improvement: $47.3 \%$ vs. $16.7 \%$ placebo) $[339,340]$. Recent experimental results showed a beneficial effect of the local treatment with Trichinella spiralis antigens in experimental colitis induced by dinitrobenzene sulfonic acid in mice, which suggest that helminth antigen-based therapy should be applied for IBD instead of infection with live parasites [341].

\section{CONCLUSION}

The intensive research over the last decade has led to better understanding of the pathophysiology of IBDs. IBDs are initiated and perpetuated by an impaired immune response against the gut microbiota in genetically susceptible individuals. Predisposition to disease is determined by genes encoding immune responses which are triggered by several environmental influences. According to the present concept the disease is caused by a combination of factors, including genetics, immune dysregulation, barrier dysfunction, the change in microbial flora and environmental stimuli. The novel therapeutics, such as monoclonal antibodies, small molecule inhibitors, peptides, and vaccines target specific signaling pathways involved in initiation, perpetuation and maintenance of intestinal inflammation. During the course of IBD several molecules were shown to be upregulated or downregulated in patients with IBD, which raised that they are potentially targets for drug development. However, in human studies many of the newly developed molecules failed to show significant biological action and had limited clinical efficacy. Moreover, antibody production to the therapeutic monoclonal antibodies may result in reduction of the efficacy of the biologics. Consequently, need for the development of additional strategies and targets is raised.

Moreover, it's also worth considering that combination of different factors may lead to the development of IBD. In addition, also the levels of cytokines potentially involved in pathophysiology of intestinal inflammation are different at the different stages of the disease; e.g. IFN- $\gamma$ is significantly higher in early stage compared with late stage of IBD [342]. Consequently, more than one therapeutic option may be necessary during the course of the disease. The "step-up" therapeutic strategy represents partly this concept, however, there are limited studies on the therapeutic efficacy of the combination of agents with different mechanism of action [12].

\section{CONFLICT OF INTEREST}

The authors confirm that this article content has no conflicts of interest.

\section{ACKNOWLEDGEMENTS}

Declared none.

\section{REFERENCES}

[1] Strober W, Fuss I, Mannon P. The fundamental basis of inflammatory bowel disease. J Clin Invest 2007; 117: 514-21.

[2] Xavier RJ, Podolsky DK. Unravelling the pathogenesis of inflammatory bowel disease. Nature 2007; 448: 427-34.

[3] Henderson P, van Limbergen JE, Schwarze J, Wilson DC. Function of the intestinal epithelium and its dysregulation in inflammatory bowel disease. Inflamm Bowel Dis 2011; 17: 382-95.

[4] Keita AV, Soderholm JD. Barrier dysfunction and bacterial uptake in the follicle-associated epithelium of ileal Crohn's disease. Ann N Y Acad Sci 2012; 1258: 125-34

[5] Kucharzik T, Maaser C, Lugering A, et al. Recent understanding of IBD pathogenesis: implications for future therapies. Inflamm Bowel Dis 2006; 12: 1068-83.

[6] Salim SY, Soderholm JD. Importance of disrupted intestinal barrier in inflammatory bowel diseases. Inflamm Bowel Dis 2011; 17: 362-81.

[7] Triantafillidis JK, Merikas E, Georgopoulos F. Current and emerging drugs for the treatment of inflammatory bowel disease. Drug Des Devel Ther 2011; 5: 185-210.

[8] Engel MA, Becker C, Reeh PW, Neurath MF. Role of sensory neurons in colitis: increasing evidence for a neuroimmune link in the gut. Inflamm Bowel Dis 2011; 4: 1030-3.

[9] MacDonald TT, Monteleone I, Fantini MC, Monteleone G. Regulation of homeostasis and inflammation in the intestine. Gastroenterology 2011; 6: 1768-75.

[10] Fuss IJ, Heller F, Boirivant M, et al. Nonclassical CD1d-restricted NK $\mathrm{T}$ cells that produce IL-13 characterize an atypical Th2 response in ulcerative colitis. J Clin Invest 2004; 10: 1490-7.

[11] Monteleone I, Vavassori P, Biancone L, Monteleone G, Pallone F. Immunoregulation in the gut: success and failures in human disease. Gut 2002; 50 (Suppl 3): 60-4.

[12] Danese S. New therapies for inflammatory bowel disease: from the bench to the bedside. Gut 2012; 61: 918-32.

[13] Lakatos PL, Szamosi T, Lakatos L. Smoking in inflammatory bowel diseases: good, bad or ugly? World J Gastroenterol 2007; 13: 6134-9. 
[14] Baumgart DC, Sandborn WJ. Inflammatory bowel disease: clinical aspects and established and evolving therapies. Lancet 2007; 369: 1641-57.

[15] Baumgart DC. The diagnosis and treatment of Crohn's disease and ulcerative colitis. Dtsch Arztebl Int 2009; 106: 123-33.

[16] Hanauer SB, Sandborn W. Management of Crohn's disease in adults. Am J Gastroenterol 2001; 96: 635-43.

[17] Hendrickson BA, Gokhale R, Cho JH. Clinical aspects and pathophysiology of inflammatory bowel disease. Clin Microbiol Rev 2002; 15: 79-94.

[18] Biancone L, Michetti P, Travis S, et al. European evidence-based Consensus on the management of ulcerative colitis: Special situations. J Crohns Colitis 2008; 2: 63-92.

[19] Itzkowitz SH, Present DH. Consensus conference: Colorectal cancer screening and surveillance in inflammatory bowel disease. Inflamm Bowel Dis 2005; 11: 314-21.

[20] Gillen CD, Walmsley RS, Prior P, Andrews HA, Allan RN. Ulcerative colitis and Crohn's disease: a comparison of the colorectal cancer risk in extensive colitis. Gut 1994; 35: 1590-2.

[21] Lakatos PL. Recent trends in the epidemiology of inflammatory bowel diseases: up or down? World J Gastroenterol 2006; 12: 6102-8.

[22] Cannom RR, Kaiser AM, Ault GT, Beart RW, Jr., Etzioni DA. Inflammatory bowel disease in the United States from 1998 to 2005: has infliximab affected surgical rates? Am Surg 2009; 75: 976-80.

[23] Orholm M, Binder V, Sorensen TI, Rasmussen LP, Kyvik KO. Concordance of inflammatory bowel disease among Danish twins. Results of a nationwide study. Scand J Gastroenterol 2000; 35: 1075-81.

[24] Sherlock P, Bell BM, Steinberg H, Almy TP. Familial occurrence of regional enteritis and ulcerative colitis. Gastroenterology 1963; 45: 413-20.

[25] Spehlmann ME, Begun AZ, Burghardt J, Lepage P, Raedler A, Schreiber S. Epidemiology of inflammatory bowel disease in a German twin cohort: results of a nationwide study. Inflamm Bowel Dis 2008; 14: $968-76$

[26] Thompson NP, Driscoll R, Pounder RE, Wakefield AJ. Genetics versus environment in inflammatory bowel disease: results of a British twin study. BMJ 1996; 312: 95-6.

[27] Tysk C, Lindberg E, Jarnerot G, Floderus-Myrhed B. Ulcerative colitis and Crohn's disease in an unselected population of monozygotic and dizygotic twins. A study of heritability and the influence of smoking. Gut 1988; 29: 990-6.

[28] Franke A, McGovern DP, Barrett JC, et al. Genome-wide metaanalysis increases to 71 the number of confirmed Crohn's disease susceptibility loci. Nat Genet 2010; 42: 1118-25.

[29] Jostins L, Ripke S, Weersma RK, et al. Host-microbe interactions have shaped the genetic architecture of inflammatory bowel disease. Nature 2012; 491: 119-24.

[30] Franchi L, Warner N, Viani K, Nunez G. Function of Nod-like receptors in microbial recognition and host defense. Immunol Rev 2009; 227: 106-28.

[31] Kersse K, Bertrand MJ, Lamkanfi M, Vandenabeele P. NOD-like receptors and the innate immune system: coping with danger, damage and death. Cytokine Growth Factor Rev 2011; 22: 257-76.

[32] Manicassamy S, Pulendran B. Modulation of adaptive immunity with Toll-like receptors. Semin Immunol 2009; 21: 185-93.

[33] Bonen DK, Ogura Y, Nicolae DL, et al. Crohn's disease-associated NOD2 variants share a signaling defect in response to lipopolysaccharide and peptidoglycan. Gastroenterology 2003; 124 : 140-6.

[34] Hugot JP, Chamaillard M, Zouali H, et al. Association of NOD2 leucine-rich repeat variants with susceptibility to Crohn's disease. Nature 2001; 411: 599-603

[35] Ogura $\mathrm{Y}$, Bonen DK, Inohara N, et al. A frameshift mutation in NOD2 associated with susceptibility to Crohn's disease. Nature 2001; 411: 603-6.

[36] Ogura Y, Saab L, Chen FF, Benito A, Inohara N, Nunez G. Genetic variation and activity of mouse Nod2, a susceptibility gene for Crohn's disease. Genomics 2003; 81: 369-77.

[37] Inoue N, Tamura K, Kinouchi Y, et al. Lack of common NOD2 variants in Japanese patients with Crohn's disease. Gastroenterology 2002; 123: 86-91.

[38] McGovern DP, Hysi P, Ahmad T, et al. Association between a complex insertion/deletion polymorphism in NOD1 (CARD4) and susceptibility to inflammatory bowel disease. Hum Mol Genet 2005; 14: 1245-50.

[39] Franke A, Ruether A, Wedemeyer N, Karlsen TH, Nebel A Schreiber S. No association between the functional CARD4 insertion/deletion polymorphism and inflammatory bowel diseases in the German population. Gut 2006; 55: 1679-80.

[40] Van Limbergen J, Russell RK, Nimmo ER, et al. Contribution of the NOD1/CARD4 insertion/deletion polymorphism +32656 to inflammatory bowel disease in Northern Europe. Inflamm Bowel Dis 2007; 13: 882-9.

[41] Pierik M, Joossens S, Van Steen K, et al. Toll-like receptor-1, -2, and -6 polymorphisms influence disease extension in inflammatory bowel diseases. Inflamm Bowel Dis 2006; 12: 1-8.

[42] Franchimont D, Vermeire S, El Housni H, et al. Deficient hostbacteria interactions in inflammatory bowel disease? The toll-like receptor (TLR)-4 Asp299gly polymorphism is associated with Crohn's disease and ulcerative colitis. Gut 2004; 53: 987-92.

[43] Brand S, Staudinger T, Schnitzler F, et al. The role of Toll-like receptor 4 Asp299Gly and Thr399Ile polymorphisms and CARD15/NOD2 mutations in the susceptibility and phenotype of Crohn's disease. Inflamm Bowel Dis 2005; 11: 645-52.

[44] Torok HP, Glas J, Tonenchi L, Mussack T, Folwaczny C. Polymorphisms of the lipopolysaccharide-signaling complex in inflammatory bowel disease: association of a mutation in the Tolllike receptor 4 gene with ulcerative colitis. Clin Immunol 2004; 112: 85-91

[45] Gazouli M, Mantzaris G, Kotsinas A, et al. Association between polymorphisms in the Toll-like receptor 4, CD14, and CARD15/NOD2 and inflammatory bowel disease in the Greek population. World J Gastroenterol 2005; 11: 681-5.

[46] Hume GE, Fowler EV, Doecke J, et al. Novel NOD2 haplotype strengthens the association between TLR4 Asp299gly and Crohn's disease in an Australian population. Inflamm Bowel Dis 2008; 14: 585-90.

[47] Rigoli L, Romano C, Caruso RA, et al. Clinical significance of NOD2/CARD15 and Toll-like receptor 4 gene single nucleotide polymorphisms in inflammatory bowel disease. World $\mathbf{J}$ Gastroenterol 2008; 14: 4454-61.

[48] Lakatos PL, Lakatos L, Szalay F, et al. Toll-like receptor 4 and NOD2/CARD15 mutations in Hungarian patients with Crohn's disease: phenotype-genotype correlations. World J Gastroenterol 2005; 11: 1489-95

[49] Browning BL, Huebner C, Petermann I, et al. Has toll-like receptor 4 been prematurely dismissed as an inflammatory bowel disease gene? Association study combined with meta-analysis shows strong evidence for association. Am J Gastroenterol 2007; 102: 2504-12.

[50] Hong J, Leung E, Fraser AG, Merriman TR, Vishnu P, Krissansen GW. TLR2, TLR4 and TLR9 polymorphisms and Crohn's disease in a New Zealand Caucasian cohort. J Gastroenterol Hepatol 2007; 22: $1760-6$

[51] Franke A, McGovern DP, Barrett JC, et al. Genome-wide metaanalysis increases to 71 the number of confirmed Crohn's disease susceptibility loci. Nat Genet 2010; 42: 1118-25.

[52] Zhernakova A, Festen EM, Franke L, et al. Genetic analysis of innate immunity in Crohn's disease and ulcerative colitis identifies two susceptibility loci harboring CARD9 and IL18RAP. Am J Hum Genet 2008; 82: 1202-10.

[53] Hampe J, Franke A, Rosenstiel P, et al. A genome-wide association scan of nonsynonymous SNPs identifies a susceptibility variant for Crohn disease in ATG16L1. Nat Genet 2007; 39: 207-11.

[54] Lakatos PL, Szamosi T, Szilvasi A, et al. ATG16L1 and IL23 receptor (IL23R) genes are associated with disease susceptibility in Hungarian CD patients. Dig Liver Dis 2008; 40: 867-73.

[55] Parkes M, Barrett JC, Prescott NJ, et al. Sequence variants in the autophagy gene IRGM and multiple other replicating loci contribute to Crohn's disease susceptibility. Nat Genet 2007; 39: 830-2.

[56] Prescott NJ, Fisher SA, Franke A, et al. A nonsynonymous SNP in ATG16L1 predisposes to ileal Crohn's disease and is independent of CARD15 and IBD5. Gastroenterology 2007; 132: 1665-71.

[57] Kaser A, Lee AH, Franke A, et al. XBP1 links ER stress to intestinal inflammation and confers genetic risk for human inflammatory bowel disease. Cell 2008; 134: 743-56. 
[58] McGovern DP, Gardet A, Torkvist L, et al. Genome-wide association identifies multiple ulcerative colitis susceptibility loci. Nat Genet 2010; 42: 332-7.

[59] Libioulle C, Louis E, Hansoul S, et al. Novel Crohn disease locus identified by genome-wide association maps to a gene desert on 5p13.1 and modulates expression of PTGER4. PLoS Genet 2007; 3: e58.

[60] Duerr RH, Taylor KD, Brant SR, et al. A genome-wide association study identifies IL23R as an inflammatory bowel disease gene. Science 2006; 314: 1461-3.

[61] Glas J, Seiderer J, Wetzke M, et al. rs1004819 is the main diseaseassociated IL23R variant in German Crohn's disease patients: combined analysis of IL23R, CARD15, and OCTN1/2 variants. PLoS One 2007; 2: e819.

[62] Barrett JC, Hansoul S, Nicolae DL, et al. Genome-wide association defines more than 30 distinct susceptibility loci for Crohn's disease. Nat Genet 2008; 40: 955-62.

[63] Hisamatsu T, Kanai T, Mikami Y, Yoneno K, Matsuoka K, Hibi T. Immune aspects of the pathogenesis of inflammatory bowel disease. Pharmacol Ther 2013; 137: 283-97.

[64] Muzes G, Molnar B, Tulassay Z, Sipos F. Changes of the cytokine profile in inflammatory bowel diseases. World J Gastroenterol 2012; 18: 5848-61.

[65] Rubino SJ, Selvanantham T, Girardin SE, Philpott DJ. Nod-like receptors in the control of intestinal inflammation. Curr Opin Immunol 2012; 24: 398-404.

[66] Zambetti LP, Laudisi F, Licandro G, Ricciardi-Castagnoli P, Mortellaro A. The rhapsody of NLRPs: master players of inflammation....and a lot more. Immunol Res 2012; 53: 78-90.

[67] Lee CC, Avalos AM, Ploegh HL. Accessory molecules for Tolllike receptors and their function. Nat Rev Immunol 2012; 12: 16879.

[68] Arpaia N, Barton GM. The impact of Toll-like receptors on bacterial virulence strategies. Curr Opin Microbiol 2013; doi:pii: S1369-5274(12)00170-1. 10.1016/j.mib.2012.11.004. [Epub ahead of print]

[69] Kawai T, Akira S. The roles of TLRs, RLRs and NLRs in pathogen recognition. Int Immunol 2009; 21: 317-37.

[70] Brown J, Wang H, Hajishengallis GN, Martin M. TLR-signaling networks: an integration of adaptor molecules, kinases, and crosstalk. J Dent Res 2011; 90: 417-27.

[71] Loo YM, Gale M, Jr. Immune signaling by RIG-I-like receptors. Immunity 2011; 34: 680-92.

[72] Drummond RA, Saijo S, Iwakura Y, Brown GD. The role of Syk/CARD9 coupled C-type lectins in antifungal immunity. Eur J Immunol 2011; 41: 276-81.

[73] Hardison SE, Brown GD. C-type lectin receptors orchestrate antifungal immunity. Nat Immunol 2012; 13: 817-22.

[74] Jager S, Stange EF, Wehkamp J. Inflammatory bowel disease: an impaired barrier disease. Langenbecks Arch Surg 2013; 398: 1-12.

[75] McGuckin MA, Eri R, Simms LA, Florin TH, Radford-Smith G. Intestinal barrier dysfunction in inflammatory bowel diseases. Inflamm Bowel Dis 2009; 15: 100-13.

[76] Salim SY, Soderholm JD. Importance of disrupted intestinal barrier in inflammatory bowel diseases. Inflamm Bowel Dis 2011; 17: 362-81.

[77] Turner JR. Intestinal mucosal barrier function in health and disease. Nat Rev Immunol 2009; 9: 799-809.

[78] Soderholm JD, Streutker C, Yang PC, et al. Increased epithelial uptake of protein antigens in the ileum of Crohn's disease mediated by tumour necrosis factor alpha. Gut 2004; 53: 1817-24.

[79] Zeissig S, Burgel N, Gunzel D, et al. Changes in expression and distribution of claudin 2, 5 and 8 lead to discontinuous tight junctions and barrier dysfunction in active Crohn's disease. Gut 2007; 56: 61-72.

[80] Cario E, Gerken G, Podolsky DK. Toll-like receptor 2 controls mucosal inflammation by regulating epithelial barrier function. Gastroenterology 2007; 132: 1359-74.

[81] Cario E, Gerken G, Podolsky DK. Toll-like receptor 2 enhances ZO-1-associated intestinal epithelial barrier integrity via protein kinase C. Gastroenterology 2004; 127: 224-38.

[82] Hiemstra IH, Bouma G, Geerts D, Kraal G, den Haan JM. Nod2 improves barrier function of intestinal epithelial cells via enhancement of TLR responses. Mol Immunol 2012; 52: 264-72.

[83] O'Hara JR, Feener TD, Fischer CD, Buret AG. Campylobacter jejuni disrupts protective Toll-like receptor 9 signaling in colonic epithelial cells and increases the severity of dextran sulfate sodiuminduced colitis in mice. Infect Immun 2012; 80: 1563-71.

[84] Guo S, Al Sadi R, Said HM, Ma TY. Lipopolysaccharide Causes an Increase in Intestinal Tight Junction Permeability in vitro and in vivo by Inducing Enterocyte Membrane Expression and Localization of TLR-4 and CD14. Am J Pathol 2013; 182: 375-87.

[85] Salzman NH. Paneth cell defensins and the regulation of the microbiome: detente at mucosal surfaces. Gut Microbes 2010; 1: 401-6.

[86] Kobayashi KS, Chamaillard M, Ogura Y, et al. Nod2-dependent regulation of innate and adaptive immunity in the intestinal tract. Science 2005; 307: 731-4.

[87] Wehkamp J, Harder J, Weichenthal M, et al. NOD2 (CARD15) mutations in Crohn's disease are associated with diminished mucosal alpha-defensin expression. Gut 2004; 53: 1658-64.

[88] Wehkamp J, Salzman NH, Porter E, et al. Reduced Paneth cell alpha-defensins in ileal Crohn's disease. Proc Natl Acad Sci USA 2005; 102: 18129-34.

[89] Simms LA, Doecke JD, Walsh MD, Huang N, Fowler EV, Radford-Smith GL. Reduced alpha-defensin expression is associated with inflammation and not NOD2 mutation status in ileal Crohn's disease. Gut 2008; 57: 903-10.

[90] Vora P, Youdim A, Thomas LS, et al. Beta-defensin-2 expression is regulated by TLR signaling in intestinal epithelial cells. J Immunol 2004; 173: 5398-405.

[91] Koon HW, Shih DQ, Chen J, et al. Cathelicidin signaling via the Toll-like receptor protects against colitis in mice. Gastroenterology 2011; 141: 1852-63.

[92] Caricilli AM, Picardi PK, de Abreu LL, et al. Gut microbiota is a key modulator of insulin resistance in TLR 2 knockout mice. PLoS Biol 2011; 9: e1001212.

[93] Elinav E, Strowig T, Kau AL, et al. NLRP6 inflammasome regulates colonic microbial ecology and risk for colitis. Cell 2011; 145: 745-57.

[94] Neurath MF, Travis SP. Mucosal healing in inflammatory bowel diseases: a systematic review. Gut 2012; 61: 1619-35.

[95] Ey B, Eyking A, Gerken G, Podolsky DK, Cario E. TLR2 mediates gap junctional intercellular communication through connexin-43 in intestinal epithelial barrier injury. J Biol Chem 2009; 284: 2233243.

[96] Fukata M, Abreu MT. Pathogen recognition receptors, cancer and inflammation in the gut. Curr Opin Pharmacol 2009; 9: 680-7.

[97] Ungaro R, Fukata M, Hsu D, et al. A novel Toll-like receptor 4 antagonist antibody ameliorates inflammation but impairs mucosal healing in murine colitis. Am J Physiol Gastrointest Liver Physiol 2009; 296: 1167-79.

[98] Zaki MH, Boyd KL, Vogel P, Kastan MB, Lamkanfi M, Kanneganti TD. The NLRP3 inflammasome protects against loss of epithelial integrity and mortality during experimental colitis. Immunity 2010; 32: 379-91.

[99] Niess JH, Brand S, Gu X, et al. CX3CR1-mediated dendritic cell access to the intestinal lumen and bacterial clearance. Science 2005; 307: 254-8.

[100] Rutella S, Locatelli F. Intestinal dendritic cells in the pathogenesis of inflammatory bowel disease. World J Gastroenterol 2011; 17: 3761-75.

[101] Stagg AJ, Hart AL, Knight SC, Kamm MA. The dendritic cell: its role in intestinal inflammation and relationship with gut bacteria. Gut 2003; 52: 1522-9.

[102] Hart AL, Al Hassi HO, Rigby RJ, et al. Characteristics of intestinal dendritic cells in inflammatory bowel diseases. Gastroenterology 2005; 129: 50-65.

[103] Ikeda Y, Akbar F, Matsui H, Onji M. Characterization of antigenpresenting dendritic cells in the peripheral blood and colonic mucosa of patients with ulcerative colitis. Eur J Gastroenterol Hepatol 2001; 13: 841-50.

[104] te Velde AA, van Kooyk Y, Braat H, et al. Increased expression of DC-SIGN+IL-12+IL-18+ and CD83+IL-12-IL-18- dendritic cell populations in the colonic mucosa of patients with Crohn's disease. Eur J Immunol 2003; 33: 143-51.

[105] Vuckovic S, Florin TH, Khalil D, et al. CD40 and CD86 upregulation with divergent CMRF44 expression on blood dendritic cells in inflammatory bowel diseases. Am J Gastroenterol 2001; 96: 2946-56.

[106] Baumgart DC, Thomas S, Przesdzing I, et al. Exaggerated inflammatory response of primary human myeloid dendritic cells to 
lipopolysaccharide in patients with inflammatory bowel disease. Clin Exp Immunol 2009; 157: 423-36.

[107] Iliev ID, Spadoni I, Mileti E, et al. Human intestinal epithelial cells promote the differentiation of tolerogenic dendritic cells. Gut 2009; 58: $1481-89$

[108] Gordon S, Taylor PR. Monocyte and macrophage heterogeneity. Nat Rev Immunol 2005; 5: 953-64.

[109] Mantovani A, Sica A, Sozzani S, Allavena P, Vecchi A, Locati M. The chemokine system in diverse forms of macrophage activation and polarization. Trends Immunol 2004; 25: 677-86.

[110] Smith AM, Rahman FZ, Hayee B, et al. Disordered macrophage cytokine secretion underlies impaired acute inflammation and bacterial clearance in Crohn's disease. J Exp Med 2009; 206: 188397.

[111] Kamada N, Hisamatsu T, Okamoto S, et al. Unique CD14 intestinal macrophages contribute to the pathogenesis of Crohn disease via IL-23/IFN-gamma axis. J Clin Invest 2008; 118: 2269-80.

[112] Nishihira J. Molecular function of macrophage migration inhibitory factor and a novel therapy for inflammatory bowel disease. Ann $\mathrm{N}$ Y Acad Sci 2012; 1271: 53-7.

[113] Roger T, Delaloye J, Chanson AL, Giddey M, Le Roy D, Calandra T. Macrophage Migration Inhibitory Factor Deficiency Is Associated With Impaired Killing of Gram-Negative Bacteria by Macrophages and Increased Susceptibility to Klebsiella pneumoniae Sepsis. J Infect Dis 2013; 207: 331-9.

[114] Roger T, David J, Glauser MP, Calandra T. MIF regulates innate immune responses through modulation of Toll-like receptor 4 . Nature 2001; 414: 920-4.

[115] Ohkawara T, Nishihira J, Takeda $\mathrm{H}$, et al. Amelioration of dextran sulfate sodium-induced colitis by anti-macrophage migration inhibitory factor antibody in mice. Gastroenterology 2002; 123: 256-70.

[116] Murakami H, Akbar SM, Matsui H, Onji M. Macrophage migration inhibitory factor in the sera and at the colonic mucosa in patients with ulcerative colitis: clinical implications and pathogenic significance. Eur J Clin Invest 2001; 31: 337-43.

[117] Takahashi N, Nishihira J, Sato $\mathrm{Y}$, et al. Involvement of macrophage migration inhibitory factor (MIF) in the mechanism of tumor cell growth. Mol Med 1998; 4: 707-14.

[118] Bouma G, Strober W. The immunological and genetic basis of inflammatory boweldisease. Nat Rev Immunol 2003; 3: 521-33.

[119] Heller F, Florian P, Bojarski C, et al. Interleukin-13 is the key effector Th2 cytokine in ulcerative colitis that affects epithelial tight junctions, apoptosis, and cell restitution. Gastroenterology 2005; 129: 550-64.

[120] Parronchi P, Romagnani P, Annunziato F, et al. Type 1 T-helper cell predominance and interleukin-12 expression in the gut of patients with Crohn's disease. Am J Pathol 1997; 150: 823-32.

[121] Manel N, Unutmaz D, Littman DR. The differentiation of human $\mathrm{T}(\mathrm{H})-17$ cells requires transforming growth factor-beta and induction of the nuclear receptor RORgammat. Nat Immunol 2008; 9: 641-9.

[122] Monteleone I, Sarra M, Pallone F, Monteleone G. Th17-related cytokines in inflammatory bowel diseases: friends or foes? Curr Mol Med 2012; 12: 592-7.

[123] Neurath MF. IL-23: a master regulator in Crohn disease. Nat Med 2007; 13: 26-8.

[124] Zhang Z, Zheng M, Bindas J, Schwarzenberger P, Kolls JK. Critical role of IL-17 receptor signaling in acute TNBS-induced colitis. Inflamm Bowel Dis 2006; 12: 382-8.

[125] Atarashi K, Nishimura J, Shima T, et al. ATP drives lamina propria $\mathrm{T}(\mathrm{H}) 17$ cell differentiation. Nature 2008; 455: 808-12.

[126] Ivanov II, Frutos RL, Manel N, et al. Specific microbiota direct the differentiation of IL-17-producing T-helper cells in the mucosa of the small intestine. Cell Host Microbe 2008; 4: 337-49.

[127] Uematsu S, Fujimoto K, Jang MH, et al. Regulation of humoral and cellular gut immunity by lamina propria dendritic cells expressing Toll-like receptor 5. Nat Immunol 2008; 9: 769-76.

[128] Hall JA, Bouladoux N, Sun CM, et al. Commensal DNA limits regulatory $\mathrm{T}$ cell conversion and is a natural adjuvant of intestinal immune responses. Immunity 2008; 29: 637-49.

[129] van Beelen AJ, Zelinkova Z, Taanman-Kueter EW, et al. Stimulation of the intracellular bacterial sensor NOD2 programs dendritic cells to promote interleukin-17 production in human memory T cells. Immunity 2007; 27: 660-9.
[130] Rahman MK, Midtling EH, Svingen PA, et al. The pathogen recognition receptor NOD2 regulates human FOXP3+ T cell survival. J Immunol 2010; 184: 7247-56.

[131] Rawlings DJ, Schwartz MA, Jackson SW, Meyer-Bahlburg A. Integration of B cell responses through Toll-like receptors and antigen receptors. Nat Rev Immunol 2012; 12: 282-94.

[132] Qin J, Li R, Raes J, Arumugam M, et al. A human gut microbial gene catalogue established by metagenomic sequencing. Nature 2010; 464: 59-65.

[133] Human Microbiome Project Consortium. Structure, function and diversity of the healthy human microbiome. Nature 2012; 486: 20714 .

[134] Claesson MJ, Jeffery IB, Conde S, et al. Gut microbiota composition correlates with diet and health in the elderly. Nature 2012; 488: 178-84.

[135] Aitken JD, Gewirtz AT. Gut microbiota in 2012: Toward understanding and manipulating the gut microbiota. Nat Rev Gastroenterol Hepatol 2013; 10: 72-4.

[136] Nicholson JK, Holmes E, Kinross J, et al. Host-gut microbiota metabolic interactions. Science 2012; 336: 1262-7.

[137] Tremaroli V, Backhed F. Functional interactions between the gut microbiota and host metabolism. Nature 2012; 489: 242-9.

[138] Barnich N, Darfeuille-Michaud A. Adherent-invasive Escherichia coli and Crohn's disease. Curr Opin Gastroenterol 2007; 23: 16-20.

[139] Feller M, Huwiler K. Stephan R, et al. Mycobacterium avium subspecies paratuberculosis and Crohn's disease: a systematic review and meta-analysis. Lancet Infect Dis 2007; 7: 607-13.

[140] Flanagan P, Campbell BJ, Rhodes JM. Bacteria in the pathogenesis of inflammatory bowel disease. Biochem Soc Trans 2011; 39: 1067-72.

[141] Prantera C, Scribano ML. Antibiotics and probiotics in inflammatory bowel disease: why, when, and how. Curr Opin Gastroenterol 2009; 25: 329-33.

[142] Wang SL, Wang ZR, Yang CQ. Meta-analysis of broad-spectrum antibiotic therapy in patients with active inflammatory bowel disease. Exp Ther Med 2012; 4: 1051-6.

[143] Deuring JJ, de Haar C, Kuipers EJ, Peppelenbosch MP, van der Woude CJ. The cell biology of the intestinal epithelium and its relation to inflammatory bowel disease. Int J Biochem Cell Biol 2013; 45: 798-806

[144] Duboc H, Rajca S, Rainteau D, et al. Connecting dysbiosis, bileacid dysmetabolism and gut inflammation in inflammatory bowel diseases. Gut 2013; 62: 531-9.

[145] Li Q, Wang C, Tang C, Li N, Li J. Molecular-phylogenetic characterization of the microbiota in ulcerated and non-ulcerated regions in the patients with Crohn's disease. PLoS One 2012; 7 : e34939.

[146] Manichanh C, Rigottier-Gois L, Bonnaud E, et al. Reduced diversity of faecal microbiota in Crohn's disease revealed by a metagenomic approach. Gut 2006; 55: 205-11.

[147] Sha S, Xu B, Wang X, et al. The biodiversity and composition of the dominant fecal microbiota in patients with inflammatory bowel disease. Diagn Microbiol Infect Dis 2013; 75: 245-51.

[148] Sokol H, Seksik P, Furet JP, et al. Low counts of Faecalibacterium prausnitzii in colitis microbiota. Inflamm Bowel Dis 2009; 15: 1183-9.

[149] Atarashi K, Tanoue T, Shima T, et al. Induction of colonic regulatory $\mathrm{T}$ cells by indigenous Clostridium species. Science 2011; 331: 337-41.

[150] Wong JM, de Souza R, Kendall CW, Emam A, Jenkins DJ. Colonic health: fermentation and short chain fatty acids. J Clin Gastroenterol 2006; 40: 235-43.

[151] Zocco MA, dal Verme LZ, Cremonini F, et al. Efficacy of Lactobacillus GG in maintaining remission of ulcerative colitis. Aliment Pharmacol Ther 2006; 23:1567-74

[152] Macho FE, Valenti V, Rockel C, et al. Anti-inflammatory capacity of selected lactobacilli in experimental colitis is driven by NOD2mediated recognition of a specific peptidoglycan-derived muropeptide. Gut 2011; 60: 1050-9.

[153] von Schillde MA, Hormannsperger G, Weiher M, et al. Lactocepin secreted by Lactobacillus exerts anti-inflammatory effects by selectively degrading proinflammatory chemokines. Cell Host Microbe 2012; 11: 387-96.

[154] Kleessen B, Kroesen AJ, Buhr HJ, Blaut M. Mucosal and invading bacteria in patients with inflammatory bowel disease compared with controls. Scand J Gastroenterol 2002; 37: 1034-41. 
[155] Lucke K, Miehlke S, Jacobs E, Schuppler M. Prevalence of Bacteroides and Prevotella spp. in ulcerative colitis. J Med Microbiol 2006; 55: 5-24.

[156] Wright DP, Rosendale DI, Robertson AM. Prevotella enzymes involved in mucin oligosaccharide degradation and evidence for a small operon of genes expressed during growth on mucin. FEMS Microbiol Lett 2000; 190: 73-9.

[157] Mazmanian SK, Round JL, Kasper DL. A microbial symbiosis factor prevents intestinal inflammatory disease. Nature 2008; 453: 620-5.

[158] Round JL, Lee SM, Li J, et al. The Toll-like receptor 2 pathway establishes colonization by a commensal of the human microbiota. Science 2011; 332: 974-7.

[159] Ruseler-van Embden JG, Both-Patoir HC. Anaerobic gramnegative faecal flora in patients with Crohn's disease and healthy subjects. Antonie Van Leeuwenhoek 1983; 49: 125-32.

[160] Philippe D, Favre L, Foata F, et al. Bifidobacterium lactis attenuates onset of inflammation in a murine model of colitis. World J Gastroenterol 2011; 17: 459-69.

[161] Furrie E, Macfarlane S, Kennedy A, et al. Synbiotic therapy (Bifidobacterium longum/Synergy 1) initiates resolution of inflammation in patients with active ulcerative colitis: a randomised controlled pilot trial. Gut 2005; 54: 242-9.

[162] Sang LX, Chang B, Zhang WL, Wu XM, Li XH, Jiang M. Remission induction and maintenance effect of probiotics on ulcerative colitis: a meta-analysis. World J Gastroenterol 2010; 16: 1908-15.

[163] Steed H, Macfarlane GT, Blackett KL, et al. Clinical trial: the microbiological and immunological effects of synbiotic consumption - a randomized double-blind placebo-controlled study in active Crohn's disease. Aliment Pharmacol Ther 2010; 32: 87283

[164] Jeon SG, Kayama H, Ueda Y, et al. Probiotic Bifidobacterium breve induces IL-10-producing Tr1 cells in the colon. PLoS Pathog 2012; 8: e1002714.

[165] Wine E, Ossa JC, Gray-Owen SD, Sherman PM. Adherent-invasive Escherichia coli, strain LF82 disrupts apical junctional complexes in polarized epithelia. BMC Microbiol 2009; 9: 180-9.

[166] Denizot J, Sivignon A, Barreau F, et al. Adherent-invasive Escherichia coli induce claudin-2 expression and barrier defect in CEABAC10 mice and Crohn's disease patients. Inflamm Bowel Dis 2012; 18: 294-304.

[167] Samba-Louaka A, Nougayrede JP, Watrin C, Oswald E, Taieb F. The enteropathogenic Escherichia coli effector Cif induces delayed apoptosis in epithelial cells. Infect Immun 2009; 77: 5471-7.

[168] Munch A, Strom M, Soderholm JD. Dihydroxy bile acids increase mucosal permeability and bacterial uptake in human colon biopsies. Scand J Gastroenterol 2007; 42: 1167-74.

[169] Stenman LK, Holma R, Eggert A, Korpela R. A novel mechanism for gut barrier dysfunction by dietary fat: epithelial disruption by hydrophobic bile acids. Am J Physiol Gastrointest Liver Physiol 2013; 304: 227-34.

[170] Muegge BD, Kuczynski J, Knights D, et al. Diet drives convergence in gut microbiome functions across mammalian phylogeny and within humans. Science 2011;332: 970-4.

[171] Triantafillidis JK, Merikas E, Gikas A. Psychological factors and stress in inflammatory bowel disease. Expert Rev Gastroenterol Hepatol 2013; 7: 225-38.

[172] Devkota S, Wang Y, Musch MW, et al. Dietary-fat-induced taurocholic acid promotes pathobiont expansion and colitis in Il10/- mice. Nature 2012; 487: 104-8

[173] Kim KA, Gu W, Lee IA, Joh EH, Kim DH. High fat diet-induced gut microbiota exacerbates inflammation and obesity in mice via the TLR4 signaling pathway. PLoS One 2012; 7: e47713.

[174] Wang TT, Dabbas B, Laperriere D, et al. Direct and indirect induction by 1,25-dihydroxyvitamin D3 of the NOD2/CARD15defensin beta2 innate immune pathway defective in Crohn disease. J Biol Chem 2010; 285: 2227-31.

[175] Jones DT, Osterman MT, Bewtra M, Lewis JD. Passive smoking and inflammatory bowel disease: a meta-analysis. Am J Gastroenterol 2008; 103: 2382-93.

[176] Kaplan GG, Hubbard J, Korzenik J, et al. The inflammatory bowel diseases and ambient air pollution: a novel association. Am J Gastroenterol 2010; 105: 2412-9.
[177] Gent AE, Hellier MD, Grace RH, Swarbrick ET, Coggon D. Inflammatory bowel disease and domestic hygiene in infancy. Lancet 1994; 343: 766-7.

[178] Weinstock JV, Elliott DE. Helminths and the IBD hygiene hypothesis. Inflamm Bowel Dis 2009; 15: 128-33.

[179] Elliott DE, Weinstock JV. Where are we on worms? Curr Opin Gastroenterol 2012; 28: 551-6.

[180] Weinstock JV, Elliott DE. Translatability of helminth therapy in inflammatory bowel diseases. Int J Parasitol 2013; 43: 245-51.

[181] Walk ST, Blum AM, Ewing SA, Weinstock JV, Young VB Alteration of the murine gut microbiota during infection with the parasitic helminth Heligmosomoides polygyrus. Inflamm Bowel Dis 2010; 16: 1841-9.

[182] Talley NJ, Abreu MT, Achkar JP, et al. An evidence-based systematic review on medical therapies for inflammatory bowe disease. Am J Gastroenterol 2011; 106 (Suppl 1): 2-25.

[183] Keyashian K, Annunziata ML, Sakuraba A, Hanauer S Management of inflammatory bowel disease: past, present and future. Expert Rev Clin Immunol 2012; 8: 303-5.

[184] Lichtiger S, Present DH, Kornbluth A, et al. Cyclosporine in severe ulcerative colitis refractory to steroid therapy. N Engl J Med 1994; 330: $1841-5$.

[185] Targan SR, Hanauer SB, van Deventer SJ, et al. A short-term study of chimeric monoclonal antibody cA2 to tumor necrosis factor alpha for Crohn's disease. Crohn's Disease cA2 Study Group. N Engl J Med 1997; 337: 1029-35.

[186] Clark M, Colombel JF, Feagan BC, et al.Proceedings of the American gastroenterological association consensus development conference on the use of biologics in the treatment of inflammatory bowel disease, June 21-23, 2006. Gastroenterology 2007; 133: 312 39.

[187] Ford AC, Sandborn WJ, Khan KJ, Hanauer SB, Talley NJ, Moayyedi P. Efficacy of biological therapies in inflammatory bowel disease: systematic review and meta-analysis. Am J Gastroenterol 2011; 106: 644-59.

[188] Tracey D, Klareskog L, Sasso EH, Salfeld JG, Tak PP. Tumor necrosis factor antagonist mechanisms of action: a comprehensive review. Pharmacol Ther 2008; 117: 244-79.

[189] Desilva S, Kaplan G, Panaccione R. Sequential therapies for Crohn's disease: optimizing conventional and biologic strategies. Rev Gastroenterol Disord 2008; 8: 109-16.

[190] Schmidt KJ, Buning J, Jankowiak C, Lehnert H, Fellermann K. Crohn's targeted therapy: myth or real goal? Curr Drug Discov Technol 2009; 6: 290-8

[191] Dignass A, Van Assche G, Lindsay JO, et al. The second European evidence-based Consensus on the diagnosis and management of Crohn's disease: Current management. J Crohns Colitis 2010; 4 28-62.

[192] Cosnes J, Nion-Larmurier I, Beaugerie L, Afchain P, Tiret E, Gendre JP. Impact of the increasing use of immunosuppressants in Crohn's disease on the need for intestinal surgery. Gut 2005; 54: 237-41.

[193] Gionchetti P, Calabrese C, Tambasco R, et al. Role of conventional therapies in the era of biological treatment in Crohn's disease. World J Gastroenterol 2011; 17: 1797-1806.

[194] Fasci SF, Aratari A, Margagnoni G, Doddato MT, Papi C. Early treatment in Crohn's disease: do we have enough evidence to reverse the therapeutic pyramid? J Gastrointestin Liver Dis 2012; 21: 67-73.

[195] Bongartz T, Sutton AJ, Sweeting MJ, Buchan I, Matteson EL, Montori V. Anti-TNF antibody therapy in rheumatoid arthritis and the risk of serious infections and malignancies: systematic review and meta-analysis of rare harmful effects in randomized controlled trials. JAMA 2006; 295: 2275-85

[196] Semerano L, Assier E, Delavallee L, Boissier MC. Kinoid of human tumor necrosis factor-alpha for rheumatoid arthritis. Expert Opin Biol Ther 2011; 11: 545-50.

[197] Paul-Clark MJ, George PM, Gatheral T, et al. Pharmacology and therapeutic potential of pattern recognition receptors. 2012; 135 : 200-15.

[198] Levine B, Kroemer G. Autophagy in the pathogenesis of disease. Cell 2008; 132: 27-42.

[199] Kuma A, Mizushima N, Ishihara N, Ohsumi Y. Formation of the approximately 350-kDa Apg12-Apg5.Apg 16 multimeric complex mediated by Apg16 oligomerization, is essential for autophagy in yeast. J Biol Chem 2002; 277(21):18619-18625 
[200] Lesage S, Zouali H, Cézard JP, et al. CARD15/NOD2 mutational analysis and genotype-phenotype correlation in 612 patients with inflammatory bowel disease. Am J Hum Genet. 2002; 70: 845-57.

[201] Fowler EV, Doecke J, Simms LA, et al. ATG16L1 T300A shows strong associations with disease subgroups in a large Australian IBD population: further support for significant disease heterogeneity. Am J Gastroenterol 2008; 103: 2519-26.

[202] Kuballa P, Huett A, Rioux JD, Daly MJ, Xavier RJ. Impaired autophagy of an intracellular pathogen induced by a Crohn's disease associated ATG16L1 variant. PLoS One 2008; 3: e3391.

[203] Cario E, Podolsky DK. Differential alteration in intestinal epithelial cell expression of toll-like receptor 3 (TLR3) and TLR4 in inflammatory bowel disease. Infect Immun 2000; 68: 7010-7.

[204] Obermeier F, Dunger N, Strauch UG, et al. Contrasting activity of cytosin-guanosin dinucleotide oligonucleotides in mice with experimental colitis. Clin Exp Immunol 2003; 134: 217-24.

[205] Vijay-Kumar M, Wu H, Aitken J, et al. Activation of toll-like receptor 3 protects against DSS-induced acute colitis. Inflamm Bowel Dis 2007; 13: 856-64.

[206] Watanabe T, Asano N, Murray PJ, et al. Muramyl dipeptide activation of nucleotide-binding oligomerization domain 2 protects mice from experimental colitis. J Clin Invest 2008; 118: 545-559.

[207] Fukata M, Abreu MT. Pathogen recognition receptors, cancer and inflammation in the gut. Curr Opin Pharmacol 2009; 9: 680-7.

[208] Hausmann M, Kiessling S, Mestermann S, et al. Toll-like receptors 2 and 4 are up-regulated during intestinal inflammation. Gastroenterology 2002; 122: 1987-2000.

[209] Ungaro R, Fukata M, Hsu D, et al. A novel Toll-like receptor 4 antagonist antibody ameliorates inflammation but impairs mucosal healing in murine colitis. Am J Physiol Gastrointest Liver Physiol 2009; 296: 1167-79.

[210] Zhang S, Cheng K, Wang X, Yin H. Selection, synthesis, and antiinflammatory evaluation of the arylidene malonate derivatives as TLR4 signaling inhibitors. Bioorg Med Chem 2012; 20: 6073-9.

[211] Bosani M, Ardizzone S, Porro GB. Biologic targeting in the treatment of inflammatory bowel diseases. Biologics 2009; 3: 77 97.

[212] Izcue A, Coombes JL, Powrie F. Regulatory T cells suppress systemic and mucosal immune activation to control intestinal inflammation. Immunol Rev 2006; 212: 256-71.

[213] Abraham C, Cho JH. Inflammatory bowel disease. N Engl J Med 2009; 361: 2066-78.

[214] Ahluwalia JP. Immunotherapy in inflammatory bowel disease. Med Clin North Am 2012; 96: 525-44.

[215] Siegmund B. Targeted therapies in inflammatory bowel disease. Dig Dis. 2009; 27: 465-9.

[216] Magro F, Portela F. Management of inflammatory bowel disease with infliximab and other anti-tumor necrosis factor alpha therapies. BioDrugs 2010; 24 (Suppl 1): 3-14

[217] Ghosh N, Chaki R, Mandal V, Lin GD, Mandal SC. Mechanisms and efficacy of immunobiologic therapies for inflammatory bowel diseases. Int Rev Immunol 2010; 29: 4-37.

[218] Danese S, Colombel JF, Peyrin-Biroulet L, Rutgeerts P, Reinisch W. Review article: the role of anti-TNF in the management of ulcerative colitis - past, present and future. Aliment Pharmacol Ther 2013; doi: 10.1111/apt.12284. [Epub ahead of print]

[219] Vandenabeele P, Declercq W, Beyaert R, Fiers W. Two tumour necrosis factor receptors: structure and function. Trends Cell Biol 1995; 5: 392-9.

[220] Papadakis KA, Targan SR. Tumor necrosis factor: biology and therapeutic inhibitors. Gastroenterology 2000; 119: 1148-57.

[221] Ina K, Itoh J, Fukushima K, et al. Resistance of Crohn's disease T cells to multiple apoptotic signals is associated with a $\mathrm{Bcl}-2 / \mathrm{Bax}$ mucosal imbalance. J Immunol 1999; 163: 1081-90.

[222] Lugering A, Schmidt M, Lugering N, Pauels HG, Domschke W, Kucharzik T. Infliximab induces apoptosis in monocytes from patients with chronic active Crohn's disease by using a caspasedependent pathway. Gastroenterology 2001; 121: 1145-57.

[223] ten Hove T, van Montfrans C, Peppelenbosch MP, van Deventer $\mathrm{SJ}$. Infliximab treatment induces apoptosis of lamina propria $\mathrm{T}$ lymphocytes in Crohn's disease. Gut 2002; 50: 206-11.

[224] Doering J, Begue B, Lentze MJ, et al. Induction of T lymphocyte apoptosis by sulphasalazine in patients with Crohn's disease. Gut 2004; 53: $1632-8$
[225] Sartor RB. Mechanisms of disease: pathogenesis of Crohn's disease and ulcerative colitis. Nat Clin Pract Gastroenterol Hepatol 2006; 3: 390-407.

[226] Tiede I, Fritz G, Strand S, et al. CD28-dependent Rac1 activation is the molecular target of azathioprine in primary human CD4+ T lymphocytes. J Clin Invest 2003; 111: 1133-45.

[227] Panaccione R, Loftus EV, Jr., Binion D, et al. Efficacy and safety of adalimumab in Canadian patients with moderate to severe Crohn's disease: results of the Adalimumab in Canadian SubjeCts with ModErate to Severe Crohn's DiseaSe (ACCESS) trial. Can J Gastroenterol 2011; 25: 419-25.

[228] Trinder MW, Lawrance IC. Efficacy of adalimumab for the management of inflammatory bowel disease in the clinical setting. J Gastroenterol Hepatol 2009; 24: 1252-7.

[229] Sandborn WJ, Van Assche G, Reinisch W, et al. Adalimumab induces and maintains clinical remission in patients with moderateto-severe ulcerative colitis. Gastroenterology 2012; 142: 257-65.

[230] Schreiber S, Rutgeerts $\mathrm{P}$, Fedorak RN, et al. A randomized, placebo-controlled trial of certolizumab pegol (CDP870) for treatment of Crohn's disease. Gastroenterology 2005; 129: 807-18.

[231] Smith LS, Nelson M, Dolder CR. Certolizumab pegol: a TNF\{alpha\} antagonist for the treatment of moderate-to-severe Crohn's disease. Ann Pharmacother 2010; 44: 333-42.

[232] Sandborn WJ, Schreiber S, Feagan BG, et al. Certolizumab pegol for active Crohn's disease: a placebo-controlled, randomized trial. Clin Gastroenterol Hepatol 2011; 9: 670-8.

[233] Sandborn WJ, Hanauer SB, Katz S, et al. Etanercept for active Crohn's disease: a randomized, double-blind, placebo-controlled trial. Gastroenterology 2001; 121: 1088-94.

[234] Evans RC, Clarke L, Heath P, Stephens S, Morris AI, Rhodes JM. Treatment of ulcerative colitis with an engineered human antiTNFalpha antibody CDP571. Aliment Pharmacol Ther 1997; 11: 1031-5

[235] Rogler G, Michetti PF, Kruger FC, et al. Active therapeutic immunization against TNF with a TNF-kinoid in Crohn's disease patients: a phase 1-2 study. Gastroenterology 2010; 138 (Suppl 1): 517.

[236] Hodgkinson L. Digestive Disease Week 2010. Turning Science into Medicine--part 2. IDrugs. 2010; 13: 424-6.

[237] Atreya R, Mudter J, Finotto S, et al. Blockade of interleukin 6 trans signaling suppresses $\mathrm{T}$-cell resistance against apoptosis in chronic intestinal inflammation: evidence in crohn disease and experimental colitis in vivo. Nat Med 2000; 6: 583-8.

[238] Yamamoto M, Yoshizaki K, Kishimoto T, Ito H. IL-6 is required for the development of Th1 cell-mediated murine colitis. J Immunol 2000; 164: 4878-82.

[239] Nishimoto N, Kishimoto T. Humanized antihuman IL-6 receptor antibody, tocilizumab. Handb Exp Pharmacol 2008; 181: 151-60.

[240] Venkiteshwaran A. Tocilizumab. MAbs 2009; 1: 432-8.

[241] Ito H, Takazoe M, Fukuda Y, et al. A pilot randomized trial of a human anti-interleukin-6 receptor monoclonal antibody in active Crohn's disease. Gastroenterology 2004; 126: 989-96.

[242] Nishimoto N. Clinical studies in patients with Castleman's disease, Crohn's disease, and rheumatoid arthritis in Japan. Clin Rev Allergy Immunol 2005; 28: 221-30.

[243] Bouma G, Strober W. The immunological and genetic basis of inflammatory bowel disease. Nat Rev Immunol 2003; 3: 521-33.

[244] Heller F, Florian P, Bojarski C, et al. Interleukin-13 is the key effector Th2 cytokine in ulcerative colitis that affects epithelial tight junctions, apoptosis, and cell restitution. Gastroenterology 2005; 129: 550-64.

[245] Rosen MJ, Frey MR, Washington MK, et al. STAT6 activation in ulcerative colitis: a new target for prevention of IL-13-induced colon epithelial cell dysfunction. Inflamm Bowel Dis 2011; 17: 2224-34

[246] US National Institutes of Health Clinical Trials [homepage on the Internet] [cited 2011] Available from: http://www.clinicaltrials.gov

[247] Mannon P, Reinisch W. Interleukin 13 and its role in gut defence and inflammation. Gut 2012; 12: 1765-73.

[248] Waetzig GH, Seegert D, Nikolaus S, Rosenstiel P, Sfikas N, Schreiber S. Differential activity and expression of mitogenactivated protein kinases in inflammatory bowel disease. Gastroenterology 2001; 120 (Suppl 1): A522. 
[249] Hommes D, van den Blink B, Plasse T, et al. Inhibition of stressactivated MAP kinases induces clinical improvement in moderate to severe Crohn's disease. Gastroenterology 2002; 122: 7-14.

[250] Schreiber S, Feagan B, D'Haens G, et al. Oral p38 mitogenactivated protein kinase inhibition with BIRB 796 for active Crohn's disease: a randomized, double-blind, placebo-controlled trial. Clin Gastroenterol Hepatol 2006; 4: 325-34.

[251] Zu YL, Qi J, Gilchrist A, et al. p38 mitogen-activated protein kinase activation is required for human neutrophil function triggered by TNF-alpha or FMLP stimulation. J Immunol 1998; 160: 1982-9.

[252] Pallone F, Fina D, Caruso R, Monteleone G. Role of IL-21 in inflammatory bowel disease. Expert Rev Clin Immunol 2010; 6: 537-41.

[253] Ajdukovic J, Tonkic A, Salamunic I, Hozo I, Simunic M, Bonacin D. Interleukins IL-33 and IL-17/IL-17A in patients with ulcerative colitis. Hepatogastroenterology 2010; 57: 1442-4.

[254] Ludwiczek O, Kaser A, Novick D, Dinarello CA, Rubinstein M, Tilg H. Elevated systemic levels of free interleukin-18 (IL-18) in patients with Crohn's disease. Eur Cytokine Netw 2005; 16: 27-33.

[255] Hueber W, Sands BE, Vandemeulebroecke M, et al. Inhibition of IL-17A by secukinumab is ineffective for Crohn's disease (CD). Proceedings of the 6th Congress of ECCO 2011. Stockholm, September 25-26th 2011; European Cancer Organisation.

[256] Herrlinger KR, Diculescu M, Fellermann K, et al. Efficacy, safety and tolerability of vidofludimus in patients with inflammatory bowel disease: The ENTRANCE study. J Crohns Colitis 2013; pii: S1873-9946(12)00417-5. doi: 10.1016/j.crohns.2012.09.016. [Epub ahead of print]

[257] Flanagan ME, Blumenkopf TA, Brissette WH, et al. Discovery of CP-690,550: a potent and selective Janus kinase (JAK) inhibitor for the treatment of autoimmune diseases and organ transplant rejection. J Med Chem 2010; 53: 8468-84.

[258] Sandborn WJ, Ghosh S, Panes J, et al. Phase 2 randomized study of CP-690,550, an oral janus kinase inhibitor, in active Crohn's disease. Proceedings of the Digestive Disease Week 2011; Chicago, Illinois, May 7-10, 2011; 140: 745.

[259] Sandborn WJ, Ghosh S, Panes J, et al. Phase 2 study of CP690,550 , and oral janus kinase inhibitor, in active ulcerative colitis. Proceedings of the Digestive Disease Week 2011; Chicago, Illinois, May 7-10, 2011; 140: 594.

[260] Van Assche G, Sandborn WJ, Feagan BG, et al. Daclizumab, a humanised monoclonal antibody to the interleukin 2 receptor (CD25), for the treatment of moderately to severely active ulcerative colitis: a randomised, double blind, placebo controlled, dose ranging trial. Gut 2006; 55: 1568-74.

[261] Sands BE, Sandborn WJ, Creed TJ, et al. Basiliximab does not increase efficacy of corticosteroids in patients with steroidrefractory ulcerative colitis. Gastroenterology 2012; 143: 356-64.

[262] Maloy KJ. The Interleukin-23 / Interleukin-17 axis in intestinal inflammation. J Intern Med 2008; 263: 584-90.

[263] Monteleone G, Fina D, Caruso R, Pallone F. New mediators of immunity and inflammation in inflammatory bowel disease. Curr Opin Gastroenterol 2006; 22: 361-4.

[264] Guan Q, Ma Y, Hillman CL, et al. Targeting IL-12/IL-23 by employing a p40 peptide-based vaccine ameliorates TNBS-induced acute and chronic murine colitis. Mol Med 2011; 17: 646-56.

[265] Mannon PJ, Fuss IJ, Mayer L, et al. Anti-interleukin-12 antibody for active Crohn's disease. N Engl J Med 2004; 351: 2069-79.

[266] Sandborn WJ, Gasink C, Gao LL, et al. Ustekinumab induction and maintenance therapy in refractory Crohn's disease. N Engl J Med 2012; 367: 1519-28.

[267] Panaccione R, Sandborn WJ, Gordon G, et al. Briakinumab (ABT874) for treatment of Crohn's disease. Proceedings of the United European Gastroenterology Week 2010; Barcelona, Spain, October 23-27, 2011; 59: OP051D.

[268] Sands BE, Jacobson EW, Sylwestrowicz T, et al. Randomized, double-blind, placebo-controlled trial of the oral interleukin-12/23 inhibitor apilimod mesylate for treatment of active Crohn's disease. Inflamm Bowel Dis 2010; 16: 1209-18.

[269] Rutgeerts P, Reinisch W, Colombel JF, et al. Preliminary results of a phase I/II study of Huzaf, an anti-IFN-monoclonal antibody, in patients with moderate to severe active Crohn's disease. Gastroenterology 2002; 122: 61.

[270] Reinisch W, de Villiers W, Bene L, et al. Fontolizumab in moderate to severe Crohn's disease: a phase 2, randomized, double- blind, placebo-controlled, multiple-dose study. Inflamm Bowel Dis 2010; 16: 233-42.

[271] Kozuch PL, Hanauer SB. General principles and pharmacology of biologics in inflammatory bowel disease. Gastroenterol Clin North Am 2006; 35: 757-73.

[272] Picarella D, Hurlbut P, Rottman J, Shi X, Butcher E, Ringler DJ. Monoclonal antibodies specific for beta 7 integrin and mucosal addressin cell adhesion molecule-1 (MAdCAM-1) reduce inflammation in the colon of scid mice reconstituted with CD45RBhigh CD4+ T cells. J Immunol 1997; 158: 2099-106.

[273] Plevy S, Salzberg B, Van Assche G, et al. A phase I study of visilizumab, a humanized anti-CD3 monoclonal antibody, in severe steroid-refractory ulcerative colitis. Gastroenterology 2007; 133: 1414-22.

[274] Baumgart DC, Targan SR, Dignass AU, et al. Prospective randomized open-label multicenter phase I/II dose escalation trial of visilizumab (HuM291) in severe steroid-refractory ulcerative colitis. Inflamm Bowel Dis 2010; 16: 620-9.

[275] Sandborn WJ, Colombel JF, Frankel M, et al. Anti-CD3 antibody visilizumab is not effective in patients with intravenous corticosteroid-refractory ulcerative colitis. Gut 2010; 59: 1485-92.

[276] Wood NJ. IBD: Visilizumab not useful for intravenous steroidrefractory ulcerative colitis. Nat Rev Gastroenterol Hepatol 2011; 8: 3 .

[277] Dumont FJ. Idec-131. Idec/eisai. Curr Opin Investig Drugs 2002; 3: 725-34.

[278] Hemler ME, Huang C, Takada Y, Schwarz L, Strominger JL, Clabby ML. Characterization of the cell surface heterodimer VLA4 and related peptides. J Biol Chem 1987; 262: 11478-85.

[279] Farstad IN, Halstensen TS, Kvale D, Fausa O, Brandtzaeg P. Topographic distribution of homing receptors on $\mathrm{B}$ and $\mathrm{T}$ cells in human gut-associated lymphoid tissue: relation of L-selectin and integrin alpha 4 beta 7 to naive and memory phenotypes. Am J Pathol 1997; 150: 187-99.

[280] Goto A, Arimura Y, Shinomura Y, Imai K, Hinoda Y. Antisense therapy of MAdCAM-1 for trinitrobenzenesulfonic acid-induced murine colitis. Inflamm Bowel Dis 2006; 12: 758-65.

[281] Sans M, Panes J, Ardite E, et al. VCAM-1 and ICAM-1 mediate leukocyte-endothelial cell adhesion in rat experimental colitis. Gastroenterology 1999; 116: 874-83.

[282] Ghosh S, Goldin E, Gordon FH, et al. Natalizumab for active Crohn's disease. N Engl J Med 2003; 348: 24-32.

[283] MacDonald JK, McDonald JW. Natalizumab for induction of remission in Crohn's disease. Cochrane Database Syst Rev 2007; (1): CD006097.

[284] Ford AC, Sandborn WJ, Khan KJ, Hanauer SB, Talley NJ, Moayyedi P. Efficacy of biological therapies in inflammatory bowel disease: systematic review and meta-analysis. Am J Gastroenterol 2011; 106: 644-59.

[285] Kappos L, Bates D, Edan G, et al. Natalizumab treatment for multiple sclerosis: updated recommendations for patient selection and monitoring. Lancet Neurol 2011; 10: 745-58.

[286] Tilg H, Kaser A. Vedolizumab, a humanized mAb against the alpha4beta7 integrin for the potential treatment of ulcerative colitis and Crohn's disease. Curr Opin Investig Drugs 2010; 11: 1295-304.

[287] Mosli MH, Feagan BG. Vedolizumab for Crohn's disease. Expert Opin Biol Ther 2013; 13: 455-63.

[288] Marsal J, Agace WW. Targeting T-cell migration in inflammatory bowel disease. J Intern Med 2012; 272: 411-29.

[289] Bennett CF, Kornbrust D, Henry S, et al. An ICAM-1 antisense oligonucleotide prevents and reverses dextran sulfate sodiuminduced colitis in mice. J Pharmacol Exp Ther 1997; 280: 9881000 .

[290] Taniguchi T, Tsukada H, Nakamura H, et al. Effects of the antiICAM-1 monoclonal antibody on dextran sodium sulphate-induced colitis in rats. J Gastroenterol Hepatol 1998; 13: 945-9.

[291] Philpott JR, Miner PB, Jr. Antisense inhibition of ICAM-1 expression as therapy provides insight into basic inflammatory pathways through early experiences in IBD. Expert Opin Biol Ther 2008; 8: 1627-32.

[292] Sandborn WJ, Faubion WA. Biologics in inflammatory bowel disease: how much progress have we made? Gut 2004; 53: 136673.

[293] Fukuzawa H, Sawada M, Kayahara T, et al. Identification of GMCSF in Paneth cells using single-cell RT-PCR. Biochem Biophys Res Commun 2003; 312: 897-902. 
[294] Ramsay RG, Micallef SJ, Williams B, et al. Colony-stimulating factor-1 promotes clonogenic growth of normal murine colonic crypt epithelial cells in vitro. J Interferon Cytokine Res 2004; 24: 416-27.

[295] Bernasconi E, Favre L, Maillard MH, et al. Granulocytemacrophage colony-stimulating factor elicits bone marrow-derived cells that promote efficient colonic mucosal healing. Inflamm Bowel Dis 2010; 16: 428-41.

[296] Sainathan SK, Hanna EM, Gong Q, et al. Granulocyte macrophage colony-stimulating factor ameliorates DSS-induced experimental colitis. Inflamm Bowel Dis 2008; 14: 88-99.

[297] Korzenik JR, Dieckgraefe BK. An open-labelled study of granulocyte colony-stimulating factor in the treatment of active Crohn's disease. Aliment Pharmacol Ther 2005; 21: 391-400.

[298] Krishnan K, Arnone B, Buchman A. Intestinal growth factors: potential use in the treatment of inflammatory bowel disease and their role in mucosal healing. Inflamm Bowel Dis 2011; 17: 41022.

[299] Moran CJ, Walters TD, Guo CH, et al. IL-10R Polymorphisms Are Associated with Very-early-onset Ulcerative Colitis. Inflamm Bowel Dis 2013; 19: 115-23.

[300] Buruiana FE, Sola I, Alonso-Coello P. Recombinant human interleukin 10 for induction of remission in Crohn's disease. Cochrane Database Syst Rev 2010; (11): CD005109.

[301] Trepicchio WL, Bozza M, Pedneault G, Dorner AJ. Recombinant human IL-11 attenuates the inflammatory response through downregulation of proinflammatory cytokine release and nitric oxide production. J Immunol 1996; 157: 3627-34.

[302] Qiu BS, Pfeiffer CJ, Keith JC, Jr. Protection by recombinant human interleukin-11 against experimental TNB-induced colitis in rats. Dig Dis Sci 1996; 41: 1625-30.

[303] Gibson DL, Montero M, Ropeleski MJ, Bergstrom KS, Ma C, Ghosh $\mathrm{S}$ et al. Interleukin-11 reduces TLR4-induced colitis in TLR2-deficient mice and restores intestinal STAT3 signaling. Gastroenterology 2010; 139: 1277-88.

[304] Herrlinger KR, Witthoeft T, Raedler A, et al. Randomized, double blind controlled trial of subcutaneous recombinant human interleukin-11 versus prednisolone in active Crohn's disease. Am J Gastroenterol 2006; 101: 793-7.

[305] Pena RC, Hanauer SB, Tomasevic R, Hunter JO, Shafran I, Graffner $\mathrm{H}$. Interferon beta-1a for the maintenance of remission in patients with Crohn's disease: results of a phase II dose-finding study. BMC Gastroenterol 2009; 9: 22.

[306] Pena-Rossi C, Schreiber S, Golubovic G, et al. Clinical trial: a multicentre, randomized, double-blind, placebo-controlled, dosefinding, phase II study of subcutaneous interferon-beta-la in moderately active ulcerative colitis. Aliment Pharmacol Ther 2008; 28: 758-67.

[307] Neurath MF, Travis SP. Mucosal healing in inflammatory bowel diseases: a systematic review. Gut 2012; 61: 1619-35

[308] Sturm A, Dignass AU. Epithelial restitution and wound healing in inflammatory bowel disease. World J Gastroenterol 2008; 14: 34853

[309] Kara E, Sungurtekin H, Sungurtekin U, Alkanat M, Ilkgul O. The effect of recombinant human growth hormone (rhGH) on trinitrobenzene sulfonic acid-induced colitis in rats: an experimental study. Inflamm Bowel Dis 2004; 10: 112-5.

[310] Slonim AE, Bulone L, Damore MB, Goldberg T, Wingertzahn MA, McKinley MJ. A preliminary study of growth hormone therapy for Crohn's disease. N Engl J Med 2000; 342: 1633-7.

[311] Procaccino F, Reinshagen M, Hoffmann P, et al. Protective effect of epidermal growth factor in an experimental model of colitis in rats. Gastroenterology 1994; 107: 12-7.

[312] Sinha A, Nightingale J, West KP, Berlanga-Acosta J, Playford RJ. Epidermal growth factor enemas with oral mesalamine for mild-tomoderate left-sided ulcerative colitis or proctitis. N Engl J Med 2003; 349: 350-7

[313] Bajaj-Elliott M, Breese E, Poulsom R, Fairclough PD, MacDonald TT. Keratinocyte growth factor in inflammatory bowel disease. Increased mRNA transcripts in ulcerative colitis compared with Crohn's disease in biopsies and isolated mucosal myofibroblasts. Am J Pathol 1997; 151: 1469-76.

[314] Egger B, Procaccino F, Sarosi I, Tolmos J, Buchler MW, Eysselein VE. Keratinocyte growth factor ameliorates dextran sodium sulfate colitis in mice. Dig Dis Sci 1999; 44: 836-44.
[315] Miceli R, Hubert M, Santiago G, et al. Efficacy of keratinocyte growth factor-2 in dextran sulfate sodium-induced murine colitis. J Pharmacol Exp Ther 1999; 290: 464-71.

[316] Sandborn WJ, Sands BE, Wolf DC, et al. Repifermin (keratinocyte growth factor-2) for the treatment of active ulcerative colitis: a randomized, double-blind, placebo-controlled, dose-escalation trial. Aliment Pharmacol Ther 2003; 17: 1355-64.

[317] Babyatsky MW, Rossiter G, Podolsky DK. Expression of transforming growth factors alpha and beta in colonic mucosa in inflammatory bowel disease. Gastroenterology 1996; 110: 975-84.

[318] Maric I, Poljak L, Zoricic S, et al. Bone morphogenetic protein-7 reduces the severity of colon tissue damage and accelerates the healing of inflammatory bowel disease in rats. J Cell Physiol 2003; 196: 258-64.

[319] Tolstanova G, Khomenko T, Deng X, et al. Neutralizing antivascular endothelial growth factor (VEGF) antibody reduces severity of experimental ulcerative colitis in rats: direct evidence for the pathogenic role of VEGF. J Pharmacol Exp Ther 2009; 328: 749-57.

[320] Scaldaferri F, Vetrano S, Sans M, et al. VEGF-A links angiogenesis and inflammation in inflammatory bowel disease pathogenesis. Gastroenterology 2009; 136: 585-95.

[321] Deng X, Szabo S, Khomenko T, et al. Novel pharmacologic approaches to the prevention and treatment of ulcerative colitis Curr Pharm Des 2013; 19: 17-28.

[322] Tolstanova G, Deng X, Khomenko T, et al. Role of anti-angiogenic factor endostatin in the pathogenesis of experimental ulcerative colitis. Life Sci 2011; 88: 74-81.

[323] Beck PL, Podolsky DK. Growth factors in inflammatory bowel disease. Inflamm Bowel Dis 1999; 5: 44-60.

[324] Eaden JA, Abrams KR, Mayberry JF. The risk of colorectal cancer in ulcerative colitis: a meta-analysis. Gut 2001; 48: 526-35.

[325] Svrcek M, Cosnes J, Tiret E, Bennis M, Parc Y, Flejou JF. Expression of epidermal growth factor receptor (EGFR) is frequent in inflammatory bowel disease (IBD)-associated intestinal cancer. Virchows Arch 2007; 450: 243-4.

[326] Dube PE, Yan F, Punit S, et al. Epidermal growth factor receptor inhibits colitis-associated cancer in mice. J Clin Invest 2012; 122 2780-92.

[327] Clavel T, Haller D. Bacteria- and host-derived mechanisms to control intestinal epithelial cell homeostasis: implications for chronic inflammation. Inflamm Bowel Dis 2007; 13: 1153-64.

[328] Barnich N, Carvalho FA, Glasser AL, et al. CEACAM6 acts as a receptor for adherent-invasive E. coli, supporting ileal mucosa colonization in Crohn disease. J Clin Invest 2007; 117: 1566-74.

[329] Chamaillard M, Dessein R. Defensins couple dysbiosis to primary immunodeficiency in Crohn's disease. World J Gastroenterol 2011; 17: 567-71

[330] Peyrin-Biroulet L, Beisner J, Wang G, et al. Peroxisome proliferator-activated receptor gamma activation is required for maintenance of innate antimicrobial immunity in the colon. Proc Natl Acad Sci USA 2010; 107: 8772-7.

[331] Lewis JD, Lichtenstein GR, Deren JJ, et al. Rosiglitazone for active ulcerative colitis: a randomized placebo-controlled trial. Gastroenterology 2008; 134: 688-95.

[332] Vanderpool C, Yan F, Polk DB. Mechanisms of probiotic action: Implications for therapeutic applications in inflammatory bowel diseases. Inflamm Bowel Dis 2008; 14: 1585-96.

[333] Grabig A, Paclik D, Guzy C, et al. Escherichia coli strain Nissle 1917 ameliorates experimental colitis via toll-like receptor 2- and toll-like receptor 4-dependent pathways. Infect Immun 2006; 74: 4075-82

[334] Benjamin JL, Hedin CR, Koutsoumpas A, et al. Randomised, double-blind, placebo-controlled trial of fructo-oligosaccharides in active Crohn's disease. Gut 2011; 60: 923-9.

[335] Meijer BJ, Dieleman LA. Probiotics in the treatment of human inflammatory bowel diseases: update 2011. J Clin Gastroenterol 2011; 45 (Suppl): 139-44.

[336] Prantera C, Scribano ML, Falasco G, Andreoli A, Luzi C. Ineffectiveness of probiotics in preventing recurrence after curative resection for Crohn's disease: a randomised controlled trial with Lactobacillus GG. Gut 2002; 51: 405-9.

[337] Mack DR. Probiotics in inflammatory bowel diseases and associated conditions. Nutrients 2011; 3: 245-64. 
[338] Anderson JL, Edney RJ, Whelan K. Systematic review: faecal microbiota transplantation in the management of inflammatory bowel disease. Aliment Pharmacol Ther 2012; 36: 503-16.

[339] Summers RW, Elliott DE, Urban JF, Jr., Thompson RA, Weinstock JV. Trichuris suis therapy for active ulcerative colitis: a randomized controlled trial. Gastroenterology 2005; 128: 825-32.

[340] Summers RW, Elliott DE, Urban JF, Jr., Thompson R, Weinstock JV. Trichuris suis therapy in Crohn's disease. Gut 2005; 54:87-90.
[341] Motomura Y, Wang H, Deng Y, El-Sharkawy RT, Verdu EF, Khan WI. Helminth antigen-based strategy to ameliorate inflammation in an experimental model of colitis. Clin Exp Immunol 2009; 155: 8895.

[342] Kugathasan S, Saubermann LJ, Smith L, et al. Mucosal T-cell immunoregulation varies in early and late inflammatory bowel disease. Gut 2007; 56: 1696-705. 